\title{
THE WELLCOME PHYSIOLOGICAL RESEARCH LABORATORIES 1894-1904: THE HOME OFFICE, PHARMACEUTICAL FIRMS, AND ANIMAL EXPERIMENTS
}

by

E. M. TANSEY*

\section{INTRODUCTION}

In late nineteenth-century Britain serious attempts were made to promote science, to provide better educational facilities for scientists, and to increase the application of the sciences in ind ustry and commerce. These included the Great Exhibition of 1851, with its emphatic display of scientific achievements; the internal reorganization of the Royal Society and its administration of a government grant to support research; the indefatigable efforts of T. H. Huxley and his associates to publicize science and its possibilities; and the increasing number of expressions of concern about the economic advantages gained by industrial competitors, particularly in Germany, which enthusiastically embraced and furthered scientific methods. ${ }^{1}$ However, there were also appreciable reservations about these new approaches; and in the medical world in particular, considerable ambivalence was expressed towards science and its practitioners. There was, for example, ready acceptance that claims to scientific expertise could confer additional status on medical practitioners and enhance the reputation of the medical profession. Nevertheless, there was also distrust, and even distaste, for an endeavour that was seen to belong more to the artisan class than to the gentlemanly profession that medicine had become. ${ }^{2}$ The pharmaceutical sciences, such as they were at this time, were especially subject to these contrary pressures. Within the developing pharmaceutical industry itself, a small but growing number of agitators compared the lack of scientific support in Britain with the strong encouragement lent to research in some American and European countries, by governments and the manufacturers themselves. At the same time, however, many medical men felt threatened by new scientific developments that they saw as encroaching upon their traditional skills; whilst others were openly disdainful of such tradesmen as chemists and druggists claiming scientific ambitions that properly belonged to the medical profession.

* E. M. Tansey, B.Sc., PhD., Wellcome Institute for the History of Medicine, 183 Euston Road, London NW1 2BP.

\footnotetext{
${ }^{1}$ Two useful summaries of these debates are provided by R. M. MacLeod 'The resources of science in Victorian England: the endowment of science movement, 1868-1900' in P. Mathias, (editor), Science and society, 1600-1900, Cambridge University Press, 1972, pp. 111-66; and P. Alter, The reluctant patron: science and the state in Britain 1850-1920, Oxford, Berg, 1987, passim, especially pp. 13-74.

2 The medical practitioners' struggle for professional status is described by M. J. Peterson, The medical profession in mid-Victorian London, Berkeley, University of California Press, 1978, passim.
} 
An additional, but hitherto unrecognized, problem was the constraint put upon medical research by the 1876 Cruelty to Animals Act, which regulated the use of living animals in experimental work. The Act had, from its very beginnings, aroused much hostility and resentment among the medical profession because of its restrictions and impositions. ${ }^{3}$ One requirement of the Act was that all premises where experiments were performed on animals had to be registered with the Home Office. Until 1901, these were either laboratories associated with hospitals, medical schools, or medical corporations, or, very occasionally, the private laboratories of medical men. The first pharmaceutical manufacturer to apply for the registration of laboratories owned by him was Henry Wellcome, proprietor of Burroughs Wellcome and Co. His submission aroused several debates about the application of the existing law to new experimental methods, the desirability of drug standardization and physiological testing, and the propriety of allowing a "commercial" manufacturer the same privileges, even for his private laboratories, accorded to medical organizations. Thus, Wellcome's application provides a focus for the study of some of the ambivalent attitudes towards science, and for an analysis of the effect of the 1876 Cruelty to Animals Act on the development of pharmaceutical research in Britain. ${ }^{4}$

\section{BURROUGHS WELLCOME AND CO.}

The pharmaceutical firm Burroughs Wellcome and Co. was established in Britain in 1880 by two American pharmacists, Silas M. Burroughs and Henry S. Wellcome. ${ }^{5}$ One of their initial aims was to introduce into European markets the type of compressed medicine succeeding in America, and in 1884 Wellcome registered the trademark "Tabloid" to describe some of these preparations. Burroughs's death, in 1895 , left Wellcome as the sole proprietor of the Company, and his financial security enabled him to indulge extensively such interests as archaeology and anthropology. ${ }^{6}$ It also

${ }^{3}$ R. D. French, Anti-vivisection and medical science in Victorian society, Princeton University Press, 1975, pp. 112-58. The comparable restrictions imposed by English patent law are discussed by $\mathrm{H}$. J. Habbakuk, American and British technology in the nineteenth century: the search for labour-saving inventions, Cambridge University Press, 1962, p. 216. See also L. H. Haber, The chemical industry during the nineteenth century: a study of the economic aspect of applied chemistry in Europe and North America, Oxford, Clarendon Press, 1958, especially 'Chemical manufacturers and their problems', pp. 186-230.

${ }^{4}$ Much material used in this study is from the Archives of the Wellcome Foundation (WF) quoted with the permission of the Wellcome Foundation Ltd., and from the Archives of the Wellcome Institute (WI), quoted, as are other WI documents, with the permission of the Trustees of the Wellcome Trust. I thank the WF Archivists Mrs R. C. E. Milligan and Mrs M. F. Williamson for their help.

${ }^{5}$ Histories of Burroughs Wellcome and Co. (BW\&Co) and biographies of its founders are few and incomplete: C. M. Wenyon, 'Sir Henry Solomon Wellcome', Obit. Not. FRS Lond. 1938, 2: 229-38; Sir Henry Wellcome, a biographical memoir, London, The Wellcome Foundation, 1953; G. MacDonald, In pursuit of excellence, London, The Wellcome Foundation, 1980; H. Turner, Henry Wellcome, the man, his collections and his legacy, London, Heinemann Educational Books and the Wellcome Trust, 1980; A. W. Haggis, 'The Life and work of Sir Henry Wellcome', WI typescript, 1942; R. C. E. Milligan, 'Henry Solomon Wellcome' in D. J. Jeremy, (editor), Dictionary of business biography, London, Butterworth, 1986, vol. 5, pp. 727-36. Details of Burroughs are included in MacDonald (above), pp. 19-21, and in obituaries, e.g., Chem. \& Drug., 1895, 46: 213-14; ibid., 254-8; Pharm. Era, 1895, 13: 210-11, 720-2. See also A. R. Hall and B. A. Bembridge, Physic and philanthropy: the Wellcome Trust 1936-1986, Cambridge University Press and The Wellcome Trust, 1986.

6 Turner, op. cit., note 5 above, pp. 37-76; Hall and Bembridge, op. cit., note 5 above, pp.11-18, 121-49; G. M. Skinner, 'Sir Henry Wellcome and his museum for the science of history', Med. Hist., 1986, 30: 383-418; G. Russell, 'The Wellcome Historical Museum's dispersal of the non-medical material, 


\section{The Wellcome Physiological Laboratories}

allowed him to establish, in addition to the research facilities within his factories, what he considered to be his private laboratories, the Wellcome Chemical (1896), Tropical (1902) and Entomological (1920) Research Laboratories. ${ }^{7}$ However, the first such scientific venture was a laboratory, opened in 1894 for the production of the then novel therapeutic agent of diphtheria antitoxin, which ultimately became known as the Wellcome Physiological Research Laboratories (WPRL). ${ }^{8}$ Although in later years it was claimed that the establishment of the WPRL was independent of both the commercial company and of Silas Burroughs, such assertions must be questioned. In 1894 the partnership between Burroughs and Wellcome still existed, although negotiations were under way to terminate it. ${ }^{9}$ It seems likely that Burroughs knew and at least tacitly approved of the establishment of the WPRL, as all major company decisions had to be ratified by both partners, but there is, as yet, no direct or circumstantial evidence of his involvement. ${ }^{10}$ Even more questionable is the independence of the laboratories from the commercial company. They were first administered directly from the Company headquarters in Snow Hill, their staff members were employees of the Company and, indeed, the main product of the laboratory, diphtheria antitoxin, was advertised and sold by the company.

THE ESTABLISHMENT OF THE WPRL AND THE EARLY PRODUCTION OF DIPHTHERIA ANTITOXIN

In 1890, Behring and Kitasato first raised diptheria antitoxin in sheep and goats, and four years later Roux further refined the technique by raising the serum in horses. These advances stimulated many institutes and companies to attempt large-scale production of therapeutic serum. ${ }^{11}$ In Britain, Burroughs Wellcome and Co. was among the first to announce its success. ${ }^{12}$ In 1894, two weeks after the British Medical

1936-1983', Museums J., 1986, 86(Suppl.): S3-S29; H. J. M. Symons, 'The development of the Wellcome Collections', Mus. Ethnograph. Gp Newsletter, 1987, 20: 1-20.

${ }^{7}$ Turner, op. cit., note 5 above, pp. 17-26; R. C. E. Milligan and E. M. Tansey, 'The early Wellcome Research Laboratories, 1894-1914', presented to the symposium on the History of the Pharmaceutical Industry, Wellcome Institute, January 1987. The 1890s saw the rise of "research within the firm", BW\&Co being among the first in Britain in this respect: M. Sanderson, The universities and British industry, 1850-1970, London, Routledge \& Kegan Paul, 1972, p. 20.

8 Turner (op. cit., note 5 above, pp. 17-8) invariably called them the Wellcome Physiological Research Laboratories, but in internal correspondence this name was first used in January 1897. The founding of the Wellcome Chemical Research Laboratories (WCRL) in 1896, after Burroughs's death, may have influenced the naming of the Physiological Laboratories.

9 Turner, op. cit., note 5 above, pp. 11-12.

10 The laboratories are not mentioned in surviving correspondence between Wellcome and Burroughs, viz., WF:HSW Private Letter Books 1881-1897, S/G/148/2; WF:D2 DW Business Correspondence 1887-1895; WF:C5 HSW Personal 3 1890-1896; WF:B3 HSW Letter/Memoranda Book 1893; WF:B3 HSW Letter/Memoranda Book Aug 1893-March 1898. F. G. Hopkins told H. H. Dale (in 1941) that Burroughs had never mentioned research to him, (and also provided the intriguing information that Wellcome had approached him before 1898 about "going to do research for the firm"). WF/180: Registration of the Wellcome Physiological Laboratories (henceforth WF/180:WPRL).

${ }^{11}$ E. von Behring and S. Kitasato, 'Ueber das Zustandekommen der Diphtherie-Immunität und der Tetanus-Immunität bei Thieren', Dtsch. Med. Wochen. 1890, 16: 1113-14. P. R. E Roux and A. L. F. J. Martin, 'Contribution à l'étude de la diphthérie (sérum thérapie)', Ann. Inst. Pasteur, 1894, 8: 609-39. The British saw this as a further example of the "made in Germany" problem e.g., Chem. \& Drug., 1896, $48: 46$. See also note 160 below.

12 Others were the British Institute of Preventive Medicine (BIPM) and Dr Emmanuel Klein of the Brown Institute: 'Supply of diphtheria antitoxin in England', Br. med. J., 1894, ii: 1063. 'The antitoxin treatment 


\section{E. M. Tansey}

Journal reported that the antitoxin could not be obtained in London, it was announced that "Messrs. Burroughs, Wellcome and Co. have arranged to supply diphtheria antitoxin. They have been preparing quietly for some months back (it takes that time before the horses become immune), and hope to have serum for distribution next week." 13

This first supply was exhausted within hours, but the Company advised that production would continue, and it apparently provided serum at a price below production costs. ${ }^{14}$ It was prepared, according to the label, "under the personal superintendence of an experienced London bacteriologist" and issued from its commercial headquarters to selected pharmacists. ${ }^{15}$ This new therapy attracted much attention and controversy, both at the time of its introduction and for many years afterwards, but a detailed discussion is beyond the scope of the present paper. ${ }^{16}$

In April 1895, T. J. Bokenham of St Bartholomew's Hospital ${ }^{17}$ was formally appointed to raise, test and issue diphtheria antitoxin on behalf of the Company, although he had been associated with it for several months already. ${ }^{18}$ From this time, the work was done at 10 Devonshire Street, Portland Place, previously unknown as an address for the Wellcome Laboratories. ${ }^{19}$ Serum production continued under the

of diphtheria: the supply of serum', ibid., p. 1452, mentions BW\&Co's use of Roux's method; advertisements for BW\&Co's antitoxins in the Lancet, 5 Jan. 1895 and the Br. med. J., 12 Jan. 1895, stressed production "at our own laboratories". The first advertisements for the BIPM antitoxin appeared in the Lancet, 12 Jan. 1895.

${ }_{13}$ Chem. \& Drug. 1894, 45: 736.

${ }^{14}$ Ibid., p. 857; Haggis, op. cit., note 5 above, p. 272. At the 1895 British Medical Association (BMA) Exhibition, BW\&Co, who promoted their "laboratory most completely equipped and under the charge of a well-known physiologist and bacteriologist" (Br. med. J, 1895, ii: 295-5), were warmly congratulated on supplying serum: Chem. \& Drug. 1895, 47: 235-6.

${ }^{15}$ Chem. \& Drug. 1895, 46: 28. BW\&Co continued to produce and advertise other diphtheria remedies, e.g. magnesium sulphate: ibid., 47: 525.

${ }^{6}$ E.g., 'De re nova', Chem. \& Drug. 1894, 45: 46; 'The anti-toxin treatment of diphtheria', ibid., 644-5; 'What is antitoxin?', ibid., 46: 16-17; 'New medication', ibid., 47: 929-30; 'The anti-toxin treatment of diphtheria', Br. med. J. 1895, i: 42-5. A useful survey is H. J. Parish, A history of immunization, Edinburgh, E. \& S. Livingstone, 1965, pp. 118-31; an American context is provided by J. M. Liebenau, 'Public health and the production and use of diphtheria anti-toxin in Philadelphia', Bull. Hist. Med., 1987, 61: 216-36.

17 Thomas Jessop Bokenham: see, e.g., Medical Directory, 1892, p. 99. An early report of BW\&Co's serum production noted that he "has distinguished himself in this branch of medicine", Chem. \& Drug., 1895, 46: 870 .

18 Bokenham's employment began 29 April 1895, according to WF:P2 Staff Records Book 1879-1902, p. 35; a date repeated in WF:K 'Notes on early diphtheria serum, a typescript history of the WPRL', n.d., c. 1927. WF:P7 gives 16 September 1894 as his starting date, although a note cautions "We have no official records of the early history of the Laboratories. All dates except very recent ones are subject to confirmation." BW\&Co paid for A. Chopping, employed "in Dr. B's lab" ty" from 26 January 1895 (WF:P2 Staff Record Book 1879-1902, p. 31); and there is correspondence between Bokenham and BW\&Co on serum-therapy prior to 29 April 1895 (WF:HSW Letter Books 1881-1897, S/G/148/2, pp. 673, 682). Perhaps he was paid a retainer from the earlier, and formally employed from the later, date. In only one Medical Directory entry did he mention BW\&Co (1897, p. 110). See also note 128 below.

${ }_{19}$ MacDonald, op. cit., note 5 above, p. 82; Turner, op. cit., note 5 above, p. 18; and 'Foundation of the Wellcome Physiological Research Laboratories', extracted from 'History of the Firm File' WF:K "from information from Dr. Dale": all give 1894 as their starting date in Charlotte Street with stables in Lisson Grove. According to Sir Henry Wellcome, op. cit., note 5 above, the Physiological Laboratories were founded in 1894 "in London"; C. H. Kellaway, 'The Wellcome Research Institution', Proc. R. Soc. Lond. $B, 1948$, 135: 259-70 would have the laboratories start "in London" in 1895. Haggis, op. cit., note 5 above, p. 272, established them in an extension to Snow Hill headquarters of BW\&Co, moving to Charlotte Street and Lisson Grove in 1896, as also claimed by H. J. Parish, 'The Wellcome Research Laboratories and immunization: a historical survey and personal memoir', typescript WF/34(n.d.). Documents in WF/ 
auspices of Burroughs Wellcome and Co., which encouraged the raising of antitoxins against other diseases. ${ }^{20}$ By 1896, the rapid development of, and associated demand for, sero-therapy led to a move from Portland Place to larger facilities at 40 Charlotte Street. By this time, it was becoming obvious to Wellcome that animal experimentation was required not only to test, quantify and standardize diphtheria antitoxin, but also to develop and expand the chemo-therapeutic work of the company by promoting vigorous physiological testing of animal-derived and chemically-manufactured pharmaceutical preparations. At the same time, the work of the laboratories was brought to the attention of the Home Office and in May 1896 it advised Wellcome that application should be made to register the premises, in accordance with the 1876 Cruelty to Animals Act, for the purposes of testing antitoxins. ${ }^{21}$

\section{THE CRUELTY TO ANIMALS ACT, $1876^{22}$}

The proposal, and subsequent passing, of the Cruelty to Animals Act (39 \& 40 Vict., c. 77) stimulated great debate both in and outside Parliament. ${ }^{23}$ The Act, which applied to experiments calculated to give pain, required every researcher to hold a personal licence, granted on the recommendation of two eminent medical or scientific authorities. Such licences were available for use only at specified premises registered with the Home Office; and certain classes of experiments required the additional sanction of Certificates (described below), also granted on the personal recommendation of eminent persons. ${ }^{24}$ The Act did state that "private places, in addition to public laboratories, could be occasionally made legally available for purposes of research experiment", but required a licensee to "perform his experiments at a place registered by the Home Secretary and subject to inspection at any time". The

180:WPRL show the laboratories at 40 Charlotte Street in autumn 1896; prior to this they were at 10 Devonshire Street, Bokenham's address in the Medical Directory from 1895 until 1898.

${ }^{20}$ BW\&Co to Bokenham, 8 April 1895, mentions antitoxins for consumption; BW\&Co to Bokenham, 29 April 1895, refers to serum therapy for erysipelas, puerperal fever, etc. "we would like you to proceed with your investigation of this with all urgency. We think it very important that we should be in the forefront with this". Wellcome to Bokenham, 15 May 1895, discussed increasing large animal immunity. All in WF:HSW Letter Books 1881-1895, S/G/148/2 pp. 673, 682, 689. Chem. \& Drug., 1896, 48: 825 reported a French anti-choleraic serum; the copy in the Wellcome Institute (originally from BW\&Co) has the marginal mark in Wellcome's writing "notify Bokenham". Anti-streptococcus serum was "prepared by myself, and supplied to the profession through the firm of Burroughs, Wellcome and Co.": T. J. Bokenham, 'Additional notes on the preparation of anti-streptococcus serum', Br. med. J., 1896, ii: 3-4.

${ }^{21}$ The Secretary of State for the Home Office (HO) learned of the serum work from The Wellcome 1896 Diary and invited BW\&Co to apply for registration, licences, and certificates. Bokenham promptly did this on Wellcome's behalf. HO to BW\&Co, 4 May 1896; Wellcome to HO, 17 July [1896] both in the Public Record Office [henceforth PRO] HO 45/11092/B21744/1. I thank the Home Office for permission to examine and quote its records, and the Departmental Record Officer for assistance.

${ }^{22}$ A contemporary summary is S. Paget, 'The Act relating to experiments on animals', in Experiments on Animals, London, T. Fisher Unwin, 1900, pp. 213-69. The correct terminology, that places were "registered" and people were "licensed", has been employed throughout this paper; contemporary usage often confused the two and direct quotes retain the original words. Confusion also arose over definitions of "experiment", "cruelty", and "pain": see R. S. Vine, 'The history of the Research Defence Society', Conquest, 1987, 176: 1-16. Likewise, the Cruelty to Animals Act was often incorrectly referred to as the "Anti-Vivisection" or "Vivisection" Act.

${ }^{23}$ See French, op. cit., note 3 above.

${ }^{24}$ These were medical professors, and the Presidents of the Royal Societies of London and Edinburgh and the Royal Colleges. 


\section{E. M. Tansey}

Inspectors were themselves medical men. G. D. Thane, for example, who was closely involved with Wellcome's application, was Professor of Anatomy at University College London. ${ }^{25}$ Although in the early years of the Act such "private places" as the "cellar at 13 Claremont, Bradford" (1886) were registered, by the 1890 s most experiments were performed in university or hospital laboratories. ${ }^{26}$

There were two questions relevant to the antitoxin work of the Wellcome laboratories: did the raising of diphtheria antitoxin itself require a licence (and hence have to be performed on registered premises)?; and did the testing and quantification of the antitoxins require a licence? Such problems had concerned the Home Office for many years. As early as December 1879 , similar questions were referred to the Law Officers of the Crown for Opinion, and they were raised again in 1894, 1895, and 1896. The variety of views expressed indicate considerable confusion. ${ }^{27}$

The 1879 Opinion was that the initial inoculation to raise antitoxins did not appear to be an experiment under the Act, but that if a Certificate was required for the work, it would have to be Certificate A, i.e. for experimentation without anaesthetics. The Law Officers cautioned that, in the public mind, Certificate A was associated with painful, rather than relatively painfree, experiments; and, (just three years after the passing of the Act), that the language of the Statute was ill-defined. The 1894 Opinion was that raising antitoxins was not an experiment as it was not for the ascertaining of a scientific truth, but that some pain might occur if, for example, excessive quantities of blood were drawn. The same Law Officers offered a substantially different Opinion the following year when the question was again referred to them: "inoculations for the purpose of testing the efficacy of a substance known to be a cure for disease and produced for the purpose of being used in particular cases, is [sic] not an experiment within the meaning of the Act." They therefore declared that inoculations made for the diagnosis or cure of disease were outside the 1876 Act. However, they maintained that similar work performed for scientific curiosity alone was an experiment, and suggested that the problem could be resolved by obtaining a binding legal decision in court. A few months later, different Law Officers offered a different Opinion: the raising of

\footnotetext{
${ }^{25}$ French, op. cit., note 3 above, pp. 143-4. The appointment of medical men as Inspectors was not uncontroversial, e.g., "one wonders whether an Inspector in such a position might possibly-again, even unwittingly-have overlooked some small infringement of the act in the interests of his own profession": J. Pellow, The Home Office 1848-1914, from clerks to bureaucrats, London, Heinemann Educational Books, 1982, p. 198.

${ }^{26}$ That the College of State Medicine had been registered was important when, in 1893, it amalgamated with the newly created BIPM (later the Jenner, and Lister, Institute): The Lister Institute of Preventive Medicine, 1891-1966, London, The Lister Institute, 1966, p. 10. The Conjoint Laboratories of the Royal Colleges of Surgeons of England and Physicians of London were registered within six months of applying in 1890; Minutes of Council, Royal College of Surgeons, 1889-1891, pp. 172, 270-1. The College records are quoted with the permission of the President and Council of the Royal College of Surgeons of England (henceforth RCS). See also Z. Cope 'The Examination Hall on the Embankment and the Research Laboratories' in The Royal College of Surgeons: a history, London, Anthony Blond, 1958, pp. 165-70; and A. M. Cooke, 'The Laboratory and Museum', in A history of the Royal College of Physicians, Oxford, Clarendon Press, 1970, vol. 3, pp. 920-30. Other applications for "private" registrations were refused at this period, e.g. HO to Seligman, 1 Mar. 1900. PRO HO156/13 p. 113.

${ }_{27}$ Legal Opinions were produced on 3 Dec. 1879, by John Holker and Hardinge Gifford; 7 July 1894 and 2 July 1895 , by R. T. Reid and Frank Lockwood; and 29 Jan. 1896, by R. E. Webster and R. B. Finlay. All documents in PRO HO45/11092/B21744/1. The letter from the HO to BW\&Co, op. cit., note 21 above, referred to the Opinion of January 1896.
} 


\section{The Wellcome Physiological Laboratories}

antitoxins in horses or asses was not an experiment because it was done to produce a particular, specified substance and not for scientific enlightenment; but testing procedures on small rodents were experiments for medical purposes and therefore within the Act, as the Act did not specify that it applied only to work for the advancement of knowledge. A further question as to whether such work was calculated to give pain evoked the response that the Act was hardly designed to cover such minor discomfort as that endured by a child with measles, but that a legal decision, obtained by a prosecution, might clarify the situation.

Thus, by the time of Wellcome's application in mid-1896, Home Office directives were that the use of an animal for a procedure of which the outcome was known and which was not calculated to cause pain, i.e. the raising of diphtheria antitoxin, was not an experiment and therefore did not come under the 1876 Act. However, the experimental use of animals for raising new antitoxins and for all testing and standardization procedures did come under the Act. For such work the premises had to be registered, and the researchers needed valid Home Office licences and, when necessary, the appropriate Certificates allowing particular experiments to be performed on specified animals. ${ }^{28}$ Consequently, Bokenham could raise diphtheria antitoxin on unregistered premises, but the resultant serum had to be tested in Home Office registered laboratories, under the authority of the appropriate licence and Certificates.

Bokenham had held a Home Office licence, with several A and B Certificates, since 1888 , and throughout his association with Burroughs Wellcome and Co. this was available at both the Conjoint Laboratories of the Royal Colleges of Surgeons and Physicians and at St Bartholomew's Hospital. ${ }^{29}$ Since he made no experiments at the Conjoint Laboratories during this time, the returns he made (43 experiments under Certificate $A$ in 1894; 36 experiments in 1895 of which 34 were under Certificate A; none in 1896; and 18 under Certificate $A$ in 1897) presumably refer to work performed at St Bartholomew's Hospital. ${ }^{30}$

Thus, without even considering the "commercial" problems, the scientific context of Wellcome's 1896 application was recognized to be important but troublesome. An

\footnotetext{
${ }^{28}$ To summarize Certificate conditions briefly: licence-only experiments were non-recovery experiments performed completely under anaesthesia. Certificate A permitted work without anaesthetics: principally simple inoculations, venesection, and feeding experiments. Certificate B covered experiments in which anaesthesia was used for only part of the procedure, i.e. for recovery surgery, with additional stringent regulations about aseptic surgical procedures and the after-care of wounds. Certificate $\mathrm{C}$ was required for demonstrations to approved professional audiences; Certificate D (which rapidly fell into disuse) was required for the demonstration of facts already known. Certificate $E$, in conjunction with an $A$ or $B$ Certificate, was needed for research on cats or dogs: in 1893 it was divided, E to accompany A and EE to accompany B, for work on these domestic animals. Finally, Certificate F, again in conjunction with Certificate A or B, was needed for experiments on horses, asses, or mules.

29 Home Office Annual Returns of Experiments [HO Returns] 1889-1900, London, HMSO. Bokenham's applications for $\mathbf{A}$ Certificates (to inoculate rodents with microbes or drugs) are documented in the Minute Book of the Association for the Advancement of Medicine by Research, 20 July 1882-18 June 1891. WI MS 5311, ff. 18, 21, 71, 76.

${ }^{30}$ Minutes of Council, RCS, 1893-1895; 1895-1897; 1897-1899. Bokenham worked there before and after his Wellcome employment (Minutes of Council, 1891-1893, 1893-1895, 1897-1899), on 'Immunity against Tubercule, Erysipelas and Scarlatina'; 'Clinical Uses of Erysipelas Toxines etc', 'Chemistry of Enteric Fever', and 'Physiological Properties of Bacterial Toxins'. See also HO Returns, 1894-1897.
} 
internal Home Office memo in July of that year, detailing all the previous Opinions, made it clear that

The question raised in the present case is not whether a License should be granted for testing experiments, but whether a private laboratory should be registered. I do not see anything in the action taken recently by the H.O. which in any way prevents this question being considered entirely on its merits. No doubt the attention of Messrs. Burroughs and Wellcome was called to the principles on which the H.O. in the future proposed to act, but I see nothing in that letter [B10121/15] which pledges the H.O. to register a private Laboratory. The testing experiments might well be carried on at a place already licensed.

The question however of registering private Laboratories for this purpose is a very important one, and the Conditions under which if at all such registration should be allowed require very careful consideration. I think in the first place it would, before arriving at any conclusion, be well to discuss the matter with Dr. Poore [the Home Office Inspector]. Afterwards it may well be that the S. of S. [Secretary of State] will wish to have advice from other medical and scientific authorities. ${ }^{31}$

Almost immediately Dr Poore ${ }^{32}$ visited the new Wellcome premises at 40 Charlotte Street and reported,

They are excellent ... now being fitted, as perfectly as possible, for Bacteriological work by Messrs. Burroughs \& Wellcome. But it is a Private Laboratory and by placing it on the Register the Home Office will be departing from its usual custom as to private houses. If the use of antitoxins of various kinds should increase as seems not improbable it may well be that every manufacturing chemist in the Country will want facilities equal to those accorded to Messrs. B\&W. . . I I therefore recommend that No. 40 Charlotte Street be Registered but before this recommendation is carried out I hope the whole question will be carefully reconsidered ....

In a different hand, at the bottom of Poore's report, the public advantages of such work are contrasted with the difficulties of creating a precedent in registering "commercial" premises. After Poore confirmed that the application could be refused without undue hardship to the Company, a letter was sent to Bokenham, informing him that testing operations must be performed on other registered premises. ${ }^{33}$

The whole issue of raising antitoxins under the 1876 Act was addressed specifically by the Home Office Inspector in his Annual Report for that year (1896), although he did not mention Wellcome's application. A summary of the 1894-1896 Returns of Experiments is given in table 1 and it shows a large increase in the total number of experiments performed, in particular those under Certificate $A$, the principal type of work to be done at the WPRL.

\footnotetext{
${ }^{31}$ HO report, 20 July 1896, compiled by Kenelm Digby, Permanent Secretary at the HO (1895-1903), addressed to Sir Matthew White Ridley, Secretary of State at the HO (1895-1900), PRO HO45/11092/ B21744/1. A postscript cautions, "The licensing of a private laboratory for commercial purposes as will be seen is a totally new departure". The letter B10121/15 is that of 4 May 1896, op.cit., note 21 above. Details of the HO staff are taken from F. Newsam, The Home Office, London, George Allen \& Unwin, 1955, p. 212; and D. A. Pickrill, Ministers of the Crown, London, Routledge \& Kegan Paul, 1981, pp. 33-4.

32 French, op. cit., note 3 above, p. 170, claimed Poore was HO Inspector from 1900, but HO Returns show him as Assistant Inspector to Professor Erichsen in April 1889, and full Inspector by 1890 . He retired in 1899 , thanked "for the delicate nature of the duties you have so ably performed". HO to Poore, 13 Feb. 1899. PRO HO156/12 p. 190.

${ }^{33}$ Report of Poore, 23 July 1896, PRO HO45/11092/B21744/1.
} 
TABLE 1: SUMMARY OF THE RETURNS OF EXPERIMENTS, 1894-1896

\begin{tabular}{ccccccc} 
& \multicolumn{2}{c}{ Licensees $^{34}$} & Total & \multicolumn{2}{c}{$\begin{array}{c}\text { Experiments } \\
\text { under }^{36}\end{array}$} & $\begin{array}{c}\text { Certificate } \\
\text { not }\end{array}$ \\
& Total & Active & places & anaesthetics & $\begin{array}{c}\text { 'A' } \\
\text { experiments }\end{array}$ \\
1894 & 185 & 129 & 40 & 1565 & 1539 & 1507 \\
1895 & 213 & 148 & 36 & 2317 & 2362 & 2317 \\
1896 & 236 & 166 & 39 & 2203 & 5297 & 5217
\end{tabular}

The Inspector recognized that "The discovery of antitoxins has led to their preparation on a large scale; but, as these remedies cannot be safely and effectually used on human beings without being previously tested upon rodents, the preparation of antitoxins has necessitated a large number of inoculations." 38 This indicates quite clearly Home Office sensitivity about the increase in animal experiments and its concern to relate the work to therapeutic advances. It might be significant, therefore, that during 1896, when Bokenham applied on behalf of the WPRL, there was no increase in the total number of registered places.

\section{RESPONSE TO THE HOME OFFICE REFUSAL OF REGISTRATION}

The Home Office's refusal to register the Wellcome laboratories aroused an immediate response from Bokenham ("Personally, I can only regret the illogical position which the Secretary of State has considered it necessary to adopt, and I hope to be in a position to advance ere long further arguments which may induce him to alter his decision"), who asked Dr Poore for precise details of how the Secretary had arrived at his decision. ${ }^{39}$ Bokenham privately admitted to Wellcome that "In my earliest days of contact with the Home Office it was carefully impressed upon me that a policy of civility did not altogether pay with them, \& that the best chance of obtaining any concession from that Department was afforded by claiming as a right what one wanted \& NOT by asking for it as a privilege!"40

He consulted further with Dr Poore and Professors Victor Horsley and Charles Roy as to the best way of resolving the situation. Horsley, Professor of Pathology at University College London, had already attracted attention from the antivivisectionist movement whilst Professor-Superintendent of the Brown Institute (1884-90). ${ }^{41}$ Charles Smart Roy had been a similar target when he was at the Brown

\footnotetext{
34 "Active licensees" performed experiments during the previous year, and do not include those who held licences but performed no experiments.

35 The registered places used by active licensees, often including several "places" within one building.

${ }^{36}$ Experiments under anaesthesia for all or part of the time, i.e. returns under licence only, or under Certificates B, B and E, B and F, or C.

${ }^{37}$ Experiments without anaesthetics (principally inoculations, venesections, etc.) i.e. under Certificates A, $A$ and $E, A$ and $F$.

${ }^{38}$ HO Returns for 1896.

${ }^{39}$ Bokenham to HO, 15 Aug. 1896; Bokenham to Poore, 21 Aug. 1896. Both in PRO HO45/11092/ B21744/2.

${ }^{40}$ Bokenham to BW\&Co, 16 Aug. 1896. WF/180:WPRL.

${ }^{41}$ See S. Paget, Sir Victor Horsley: a study of his life and work, London, Constable \& Co., 1919; J. B. Lyons, Citizen surgeon, London, Peter Dawney, 1966, particularly chapter 13, 'Experiments on animals', pp. 130-50.
} 
Institute, and had been advised by the Association for the Advancement of Medicine by Research to buy dog licences for his experimental animals, in an attempt to placate anti-vivisectionist hostility. ${ }^{42}$ Bokenham reported that Horsley was particularly sympathetic and "almost the only man whom the Home Office fear... I do not think any more powerful ally could be wanted; he will give me all the assistance in his power, and he thoroughly understands how to tackle the Authorities", adding later, "I did not take a single step or make any communication to the Home Office or to Dr Poore, without in each instance having discussed the matter fully with Prof. Horsley \& submitted all written communications to him for \& received criticism." 43

How far Wellcome was convinced by these assertions is uncertain, as a note on the bottom of Bokenham's letter cautions "Mr. Sm." (J. C. Smith, a senior employee of Burroughs, Wellcome who frequently dealt with the laboratories on Wellcome's behalf) "on all points consult with Mr. C.F." (Chune Fletcher, a close friend of and medical adviser to Wellcome, particularly on matters of medical etiquette). ${ }^{44}$

Although Bokenham appeared confident that he was not infringing the existing regulations because the inoculations did not cause the animals pain, it is not at all clear where his experiments were conducted. One week later, he appeared less sure of his position. "I have secured so much professional sympathy that I have little doubt as to ultimately triumphing: but in the meantime I am left no alternative-as far as the testing operations are concerned-but to entirely ignore the bearings of the Act upon them. This the Home Office well knows, \& it will probably shut its eyes to my irregularities!"45

Wellcome himself suggested that 'If the matter is presented to the Home Office as a transfer from 10, Devonshire to 40, Charlotte St. will they not act differently?" and received the immediate reply from Bokenham that the existing laboratories were not registered under the Act. ${ }^{46}$ Chune Fletcher, who had been consulted, raised several pertinent questions: "How is it that all the present work can be done on unregistered premises? At what point in vivisection does registration become necessary?"47 Bokenham, however, does not appear to have addressed these points and continued to take personal issue with the Home Office.

You have refused, \& I can only take it that as you now know, even if you were before ignorant, the impossibility of my complying with the restrictions recently imposed, your

\footnotetext{
42 In 1896, Roy was Professor of Pathology in Cambridge, [Charles Scott Sherrington], 'C. S. Roy 1854-1897', Obit. Not. FRS Lond., 1904, 1: 131-6. AAMR Minutes of the Council and Executive Committee 1882-1891, 30 May 1890, WI MS 5310 f.58.

${ }^{43}$ Op. cit., note 40 above; Bokenham to BW\&Co 21 Aug. 1896. WF/180:WPRL.

44 "I suppose that Alfred Chune Fletcher, the Medical Officer to the Charterhouse, ... knew him [Wellcome] better than anybody else", Sir Henry Dale to Elliott, 6 June 1958. Dale Papers, The Royal Society (henceforward RS 93HD), T. R. Elliott 36.4.29. The papers were consulted with the permission of the late Lady Todd and quoted with the permission of the Royal Society. See also WF:C4.WE.HSW/ Friends/Chune Fletcher.

${ }_{45}$ Bokenham to BW\&Co, 28 Aug. 1896. WF/180 WPRL. The "irregularities" are unclear, unless Bokenham was carrying out experiments at 10 Devonshire Street. One "irregularity" in the past was an injection of ortho-nitro-toluidine into a "buck rabit" (sic), in the 'P. Lab.' of the Chemical Works of BW\&Co on 22 February 1890: the animal died with "stentorious breathing". This was clearly illegal, but is the only account I have found of any such practice. WF/7:Chemical Record Books, p. 179.

${ }^{46} \mathrm{Op}$. cit., note 43 above; copy of letter in note 40 above annotated by Wellcome.

${ }^{47}$ Memo from The Charterhouse (Chune Fletcher), undated but it mentions Bokenham and was therefore written between 1896 and 1897 . WF/180:WPRL.
} 
persistence in refusing registration must be understood as indicating that you have no REAL desire to bring these testing operations under the regular observation of your Inspector [all underlined in red by a Home Office official]. If you maintain that I am in error in this respect, I can only say that the imposition of such impracticable regulations and vexatious restrictions shows the utter disregard of your department for the convenience of members of my Profession, \& a lack of appreciation on your part of the value of their time.

He further informed the Home Office that there was no longer adequate space available for him at either the Conjoint or St Bartholomew's laboratories, and that if they had not intended to register the Wellcome laboratories, then the Home Office letter of 4 May (suggesting that Wellcome apply for registration) was "quite unjustifiable and a deliberate attempt to mislead us and to give us unnecessary trouble". 48 Not suprisingly, Home Office officials considered this to be "an illmannered letter" although they noted that "it contains the important argument that the applicant finds it impossible to obtain space for his experiments". ${ }^{49}$ Despite Bokenham's assurances that "My authority for this statement is unquestionable"; the Home Office sought its own verification and eventually concluded that Bokenham had made no application for further space and was not even using the facilities already available to him. ${ }^{50}$

In the meantime, the Wellcome laboratories moved to their newly equipped premises in Charlotte Street, with stabling facilities for eight horses in Lisson Grove, and diphtheria antitoxin production continued. Whether Bokenham intended to proceed with his arguments against the Home Office is not known: several problems arose with the serum production that may have distracted his, and the Company's, attention from the problems of registration.

\section{THE LANCET SPECIAL COMMISSION ON DIPHTHERIA ANTI-TOXIC SERUM, 1896}

In the middle of 1896, the Lancet published a commissioned report on the relative strengths of diphtheria antitoxins produced by nine institutions, ${ }^{51}$ of which three were British: the British Institute of Preventive Medicine (BIPM), ${ }^{52}$ the Bacteriological Institute, Leicester, ${ }^{53}$ and Burroughs Wellcome and Co. The sera from all three were

48 Bokenham to the Home Secretary, 1 Sept. 1896. PRO HO45/11092/B21744/3.

${ }^{49}$ HO Memo 4 Sept. 1896. PRO HO45/11092/B21744/3.

50 Bokenham to the Home Secretary, 7 Sept. 1896; Report by Sir James Russell (HO Inspector for Scotland) 12 Sept. 1896, affirming that antitoxins should be tested in public laboratories, and reporting that Dr Noel Paton, Superintendent of the Laboratory of the Royal College of Physicians of Edinburgh, considered much commercial produce to be worthless and that efforts by laboratories such as his own should be supported. HO Minute by Digby, 10 Oct. 1896. All in PRO HO45/11092/B21744/4.

51 'The Lancet Special Commission on the Relative Strengths of Diphtheria Anti-Toxic Serums', Lancet, 1896, ii: 182-95. The other companies were Meister, Lucius \& Brüning, Hoechst-on-Main; Schering, Berlin; Merck, Darmstadt; Institut Pasteur, Paris; Institut Sérothérapique, Brussels; Vogt, Geneva. Editorial comment, ibid., p.196.

${ }^{52}$ See note 20 above. When BIPM moved to the Thames Embankment, the HO registration was transferred to the premises, which included a purpose-built animal house and a small operating theatre. Pharmaceut. J., 1898, 61: 462-4.

53 Interestingly, this Institute had been established by a commercial company, John Richardson \& Co., but control had been handed over to the Leicester Medical Society: Lancet, 1895, i: 1003; ibid., 1896, i: 569-70; Chem. \& Drug., 1895, 46: 597; ibid., 1896, 48: 356. This was, apparently, at the HO's insistence that the laboratories be managed in a "scientific" spirit: memo by Poore, 7 Oct. 1896. PRO HO45/1 1092/B21744/4. 
below the claimed "strength" (in numbers of antitoxin units per vial); the specific charge against Burroughs Wellcome and Co. was that instead of the advertised 600 units per vial, the tested strength was from 45 to 300 units in the liquid serum (6 samples) and from 40 to 300 units in the dried serum (5 samples). ${ }^{54}$ According to the Chemist and Druggist, this report provided one more example of the " 'made-in-Germany' problem which haunts British technologists", and it was noted that the German Government offered support and facilities at several levels for the production of antitoxin far beyond that available to British manufacturers. Strangely, but perhaps significantly, the problems of British firms working within the 1876 Act were not mentioned, despite the strong assertion that "Guinea-pigs are the test-tubes in an analysis of this kind". A simultaneous report in the Pharmaceutical Journal, about animal-derived therapeutics, provided a rare acknowledgement that

The preliminary investigations must of necessity be carried out by the physiologist, but the chemical work now falls to the lot of the manufacturing chemist, and as patient physiological investigations are necessary, they are principally prepared in Germany, under medical supervision, and without the vexatious interference of the Vivisection Act.

However, the same journal's later call for British manufacturers to "set their house in order" over drug standardization ignored the particular restrictions and problems imposed by the 1876 Act. ${ }^{55}$

The Lancet survey provoked questions in the House of Commons about the low standards of British manufacturers compared with their Continental, particularly German, counterparts, but again there was no mention of the legal constraints operating in Britain. ${ }^{56}$ The report caused a considerable stir within the Wellcome organization and letters to the Lancet from both the Company and Bokenham questioned the discrepancies highlighted by the Special Commissioners and offered every facility for further joint testing under an independent authority. ${ }^{57}$ Although press commentators applauded this response, it was rejected by the Lancet as incompatible with the character of their Special Commissions, although it did offer to provide duplicates of their test samples for re-analysis. ${ }^{58}$ On behalf of the Company, Fletcher Moulton QC MP was retained for advice to draft a suitable reply to the Lancet. ${ }^{59}$ Unfortunately, Bokenham,

The Institute produced several antitoxins (Lancet, 1896, i: 788; ibid., 1896, ii: 127, 1484-5), and was registered from 1895 until 1897. The licensees included C. J. Bond, a later member of the first Medical Research Committee. See J. B. Walker, 'Charles John Bond of Leicester (1856-1939)', J. R. Soc. Med., 1984, 77: 316-24; A. L. Thomson, Half-a-century of medical research, London, HMSO, 1973, vol. 1, p. 21.

${ }^{54}$ Lancet, 1896, ii: $186-7$; the problem of strength was raised as early as October 1894, in 'Anti-diphtheritic serum', Pharmaceut. J., 1894, 54: 291-2.

55 'About diphtheria-serum', Chem. \& Drug., 1896, 49: 121-2; Pharmaceut. J., 1896, 57: 84; ibid., 1898, 60: 596. A discussion of the limitations of the Victorian and Edwardian education of businessmen may be found in D. C. Coleman's 'Gentlemen and players', Econ. Hist. Rev., 1973, 26: 92-116. See also 'A chemical contrast', Chem. \& Drug., 1896, 49: 788-9; and note 137 below.

56 Lancet, 'Report from the House of Commons', 1896, ii: 418.

57 Bokenham to the Lancet, 1896, ii: 271-2; BW\&Co to the Lancet, ibid., p. 272.

58 'The relative strength of diphtheria anti-toxin', Pharmaceut. J., 1896, 57: 102; 'Diphtheria anti-toxic serums', Chem. \& Drug., 1896, 49: 223. Lancet, 1896, ii: 316-17.

59 BW\&Co to Fletcher Moulton, 31 July 1896, on receiving a telegram from Wellcome: WF:HSW Letter Books 1881-1897, S/G/148/2, p. 806. See also H. F. Moulton, The life of Lord Moulton, London, Nisbet 
who took the Commissioners' report and the Lancet's refusal of joint testing personally, injudiciously claimed, "... I know that the results obtained by your Commissioners are incorrect", and questioned the experience and expertise of the Commissioners in comparison to his own. ${ }^{60}$ Not suprisingly, the Lancet responded strongly to these "preposterous" allegations and maintained that "Messrs. Burroughs, Wellcome \& Co. owe it to their well-merited reputation for drugs that this question should be placed on some more satisfactory footing."61

At this point, Henry Wellcome himself became involved in the defence of the good name and the commercial standing of the company, of which he was now the sole proprietor. He wrote to Bokenham for precise details of the samples tested by the Lancet, sought the advice of Fletcher Moulton and referred the entire issue to Chune Fletcher. ${ }^{62} \mathrm{He}$ instructed J. C. Smith from the Company to ascertain what steps Bokenham had taken and to explore the possibility of an independent referee re-testing the disputed serum. Smith discovered that samples corresponding with those tested had not been retained, although it was possible to obtain duplicates from the Lancet, and reported that he and Bokenham could come to no agreement about a suitable referee. ${ }^{63}$

Instead of providing Wellcome with the requested information about serum samples, Bokenham left the country for a European tour, ostensibly to study foreign antitoxin production. ${ }^{64}$ On his return he demonstrated his reluctance to test any samples that might be obtained from the Lancet, although he created deliberate confusion about his willingness to do so. ${ }^{65}$ (Of note here is that Bokenham performed, or admitted to performing, no testing experiments at all during 1896). ${ }^{66}$ By the beginning of December 1896, Wellcome was losing his patience and handed the investigation over to Dr Alfred Kanthack, ${ }^{67}$

as I am determined that the source of error shall be discovered whether it be on the side of the 'Lancet' or ourselves ... I shall be obliged if you [Dr Bokenham] will on

and Co., 1922, particularly 'Lord Moulton and science', pp. 105-45; and WF:HSW/Friends/Lord Moulton.

${ }^{60}$ Bokenham to the Lancet, 1896, ii: 489-90; editorial, ibid., p. 490.

${ }^{61}$ Ibid. After a paper by Bokenham at a meeting of the BMA, the Lancet again questioned his determination of antitoxin strength and reiterated the vital importance of the subject for the medical profession: Lancet, 1896, ii: 544-5. There was no further correspondence, as Chune Fletcher advised that it would only encourage people to believe there was substance in the debate: "It would be better now to let the matter drop if there is a shadow of a doubt as to Dr. Bokenham's results”. BW\&Co to Wellcome, 21 Aug. 1896, WF:HSW Letter Books 1881-1897, S/G/148/2, p. 818.

62 BW\&Co to Bokenham, 24 Aug. 1896, ibid., p. 821. BW\&Co to Moulton, 31 July, 19 and 21 Aug. 1896, ibid., pp. 806, 814, 819-20. BW\&Co to Chune Fletcher, n.d., but between 19 and 21 Aug. 1896, asking for his opinion, ibid., p. 816. See also WF:C4 WE:HSW/Friends/Chune Fletcher.

${ }^{63}$ BW\&Co to Wellcome, 19 Aug. 1896, WF:HSW Letter Books 1881-1897, S/G/148/2, p. 815.

${ }^{64}$ BW\&Co to Bokenham, 1 Oct. 1896, ibid., p. 855. "Mr Wellcome quite expected that you would send brief reports from each place that you visit, a full report being handed in on your return. We call your special attention to this matter".

${ }^{65}$ BW\&Co to Wellcome, 19 Aug. 1896, ibid., p. 833; BW\&Co to Wellcome, 4 Sept. 1896, ibid., p. 840; BW\&Co to Wellcome, 4 Sept. 1896, ibid., pp. 844-5.

${ }^{66}$ See note 30 above.

${ }^{67}$ A. A. Kanthack (1863-98) Director of the Pathological Department at St Bartholomew's Hospital, succeeded C. S. Roy (see note 42 above) at Cambridge: Br. med. J., 1898, ii: 1941-2. As early as 16 October 1896, BW\&Co asked Chune Fletcher to caution Kanthack about "the matter in hand"; thus negotiations 


\section{E. M. Tansey}

hearing from Dr. Kanthack immediately make the necessary arrangements for carrying the matter through on the lines indicated. ${ }^{68}$

"The lines indicated" were Wellcome's precise, detailed instructions for analysing the Lancet's findings. He had considered, and dismissed, the idea of direct prejudice against the Company on the part of the Lancet, realizing that the wide variety in reported strength of the tested sera indicated considerable inconsistencies within Burroughs Wellcome and Co. products, because samples from other companies, tested in exactly the same way, were not only uniform but of consistently higher strength. ${ }^{69}$

As if the Lancet report were not enough, a further blow struck the laboratories on 21 December, when the Company received a letter from Dr J. W. Washbourn, a prominent bacteriologist:

Dr. Lucas of Burwell, Cambridge sent me an unopened bottle of your Antidiphtherical Serum today for examination. I am sorry to inform you that it is full of bacteria, and consequently unfit for use. I though it wise to let you know at once because Dr. Lucas has had two deaths from vomiting and diarrhoea occurring shortly after injection with Serum obtained from your firm. ${ }^{70}$

Company staff sprang into immediate action, writing to both Washbourn and Lucas, demanding that Bokenham visit Washbourn to discuss the problem, and sending the suspect vial to Kanthack for urgent analysis. ${ }^{71}$

By this time, the Company had acquired from their salesmen several samples of both liquid and dry serum, six of which corresponded to batches used by the Lancet, and these were dispatched for re-testing. ${ }^{72}$ The "Lucas matter" was closely watched, as the Company realized the serious and damaging nature of the allegations against their product. They monitored Bokenham's correspondence with Lucas, ${ }^{73}$ and one report to Wellcome stressed that "The communication that Dr. Bokenham proposed to send to Dr. Lucas was an impossible one, and I had no hesitation in at once condemning it. I hope you will approve the final draft." "74 Fortunately for the Company, Lucas, contrary to Washbourn's advice, decided "for many reasons" not to publish details of

were proceeding several months prior to his open association with the Company: WF:HSW Letter Books 1881-1897, S/G/148/2, p. 864. Wellcome personally contributed to the memorial fund established after Kanthack's early death: Wellcome to Drysdale, 23 March 1899, WF.C5 HSW: Personal 3 1899-1901, p. 40.

${ }^{68}$ Wellcome to Bokenham, 3 Dec. 1896. WF:HSW Letter Books 1881-1897, S/G/148/2, p. 882.

${ }^{69}$ BW\&Co to Kanthack, 3 Dec. 1896, ibid., p. 881 . Detailed instructions in 'Antidiptheritic serum', 3 Dec. 1896, ibid., pp. 883-6.

70 J. W. Washbourn (1863-1902) was later Physician to Guy's Hospital. One obituary stressed his "stability and thoroughness": Trans. epidem. Soc. Lond., 1902, 21: 151-4. Washbourn to BW\&Co, quoted in the letter BW\&Co to Bokenham, 22 Dec. 1896: WF:HSW Letter Books 1881-1897, S/G/148/2, p. 903.

${ }^{71}$ BW\&Co to Wasbourn, 22 Dec. 1896, ibid., p. 904; BW\&Co to Lucas, 24 Dec. 1896 “certainly no trouble must be spared to investigate this matter", although the author shrewdly added, "we note that you used part of the same supply of serum with good results": ibid., p. 910.

72 BW\&Co to Kanthack, 23 Dec. 1896, ibid., p. 902.

73 BW\&Co to Bokenham, 12 Jan. 1897, ibid., p. 917. Bokenham was sent a draft letter, writing paper, envelope, and carbon paper for him to write to Lucas and provide a copy for the Company: "the Laboratories" were apparently not independent enough to have their own stationery. Wellcome to Dowson, 2 Jan. 1902, WF:E2 DW 'WPRL 1895-1922'.

${ }^{74}$ BW\&Co to Wellcome, 13 Jan. 1897, WF:HSW Letter Books 1881-1897, S/G/148/2, p. 920. 
the case. The reasons can only be conjectured, although the affair may have reflected badly on Lucas himself. ${ }^{75}$

Bokenham's tenure was running out: Dr Walter Dowson ${ }^{76}$ had been "installed as a pupil under Dr. Kanthack by Mr. Chune Fletcher with the idea of his acting for us either as assistant to Dr. Bokenham, or even if necessary to assume the supreme control of the Wellcome Physiological Laboratories." bacteriologist, was also drafted into temporary service although he remained in Cambridge to perform the necessary analytical work. ${ }^{78}$ When Cobbett did visit London, he exacerbated the delicacy of the situation, as Bokenham, despite forewarning from both Kanthack and Sudlow, gave him "a very cold reception ... pretending he knew nothing at all about his coming or what he was to do." For his part, Cobbett indiscreetly revealed that his instructions were from the Company, and considerable tact had to be exercised "both as regards the visits of Mr. Cobbett and also with regard to the examination by Dr. Kanthack of all serums that were received from Dr. Bokenham, a matter upon which he evidently felt very sore", although recent developments opened "up a very encouraging view with regard to the future of the Wellcome Physiological Laboratories."79

Very soon, however, Bokenham was refusing to collaborate with Kanthack, claiming that the Cambridge test methods were incompatible with his own and therefore invalid. ${ }^{80}$ This attitude forced the Company management to intervene directly once more. "We have to request that you will immediately recommence the preparation and issue of the sera which will continue to be checked as at present." Bokenham's misdemeanours did not stop there. He requested, without Company authority, a sample of the Conjoint Laboratories' Diphtheria Toxin, thus attracting unwelcome publicity, ${ }^{82}$ and he was reluctant to provide details of his procedures and experiments to either the Company or the Cambridge bacteriologists. ${ }^{83}$ This state of affairs continued for a further few unhappy months until Henry Wellcome could bear

${ }^{75}$ BW\&Co to Wellcome, 6 Jan. 1897, ibid., p. 915.

${ }^{76}$ Dowson (1856-1919) studied at Cambridge, before practising in Bristol. An inheritance enabled him to work in the Department of Pathology, Cambridge, for a few months and it was there that Wellcome approached first Cobbett, and then Dowson, to work for him. J. Peile, Biographical register of Christ's College 1505-1905, Cambridge University Press, 1913, p. 647; Dale to Oakley, 11 Feb. 1966, RS:93HD 65.5, Brockwell Hall, 1952-1967; W. Dowson, "Diphtheria in older and new Bristol', Trans. epidem. Soc., 1896, 15: 17-47. See also note 206 below.

77 Op. cit., note 74 above; this is the first reference I can find to the Wellcome Physiological Laboratories. However, until the move to Herne Hill (see notes 89 and 90 below) there was no consistent title: e.g., W'ellcome to Bokenham, 14 Dec. 1896 (WF:C5 HSW Personal 2, 1896-1899, p. 39), referred to the Physiological Laboratories; and BW\&Co to H. E. Littledale, 1 Apr. 1898 (WF:HSW Letter Books 1897-1898, S/G/148/3, pp. 517-8, referred to the Bacteriological Laboratories.

${ }_{78}^{78}$ BW \& o to Bokenham, introducing Cobbett, "to carry out all experiments and work in connection with the preparation of serums in every detail, both at the laboratories and at the Stables, that Dr. Kanthack desires": 19 Jan. 1897, WF:HSW Letter Books 1897-1898, S/G/148/3, p. 927. For Cobbett see the Lancet, 1947, ii: 391-2.

${ }_{79}$ BW\&Co to Wellcome, 27 Jan. 1897, WF:HSW Letter Books 1881-1897, S/G/148/2, pp. 930-3.

${ }^{80}$ BW\&Co to Kanthack, 13 July 1897, WF:HSW Letter Books 1897-1898, S/G/148/3, p. 42.

${ }^{81}$ BW\&Co to Bokenham, 22 July 1897 , ibid., p. 48.

${ }^{82}$ BW\&Co to Bokenham, 27 July 1897, ibid., p. 55. Minutes of Council, RCS, 1897-1899, 23 July 1897, p. 32 .

${ }_{83}$ BW\&Co to Bokenham, 5 Aug. and 24 Sept. 1897, WF:HSW Letter Books 1897-1898, S/G/148/3, pp. 61, 83; BW\&Co to Cobbett, 25 and 27 Sept. 1897, ibid., pp. 84, 86. 


\section{E. M. Tansey}

it no longer. At the end of September, he wrote to Bokenham, urging him to take the "honourable" course of resigning, and offered three months' salary plus the month's salary owing to him and the three month's salary in lieu of notice as agreed in his contract. Furthermore, Wellcome promised not to mention the manner of Bokenham's departure, in consideration of his professional position. ${ }^{84}$ Bokenham's reply, if any, is not on record.

Laboratory equipment and materials were transferred to Cobbett and Dowson, who "will take over control of our Physiological Laboratories and Stables" and formal arrangements were made with Dowson, who was appointed Director of the Laboratories at the beginning of October ${ }^{85}$ with the clear proviso, stated in his contract, that any publications must have Wellcome's approval, and that he was "to advise us on all physiological questions arising in our business when requested to do so". 86

After these changes the laboratories continued to produce antitoxins and there were no further major problems about contamination or strength. ${ }^{87}$ The arrangements with Kanthack and Cobbett lapsed whilst the demand for serum necessitated expansion. The facilities in Charlotte Street were seen to be inadequate and in 1898 the Company began looking for new premises for the WPRL.

\section{THE MOVE TO HERNE HILL AND THE DEVELOPMENT OF RESEARCH}

In August 1898, Brockwell Hall in Herne Hill, South London, was identified as a suitable site, and in November Henry Wellcome acquired a long-term lease on the property and undertook its extensive conversion, "carried out at very great expense, and no pains, labour, or money have been spared in rendering the equipment and appointments most complete." 88 By May 1899, Dowson and his small staff had moved from Charlotte Street ${ }^{89}$ and it was at this point that the establishment was publicly recognized as the Wellcome Physiological Research Laboratories. Descriptions of the experimental laboratories, incubation chambers, packing rooms, and stabling facilities soon appeared in professional journals and in the WPRL's own publications and advertisments. ${ }^{90}$ There were facilities for bacteriological, chemical,

${ }^{84}$ BW\&Co (handwritten by Wellcome) to Bokenham, 29 Sept. 1897, ibid., pp. 93-4.

${ }^{85}$ BW\&Co to Bokenham, 29 Sept. 1897, ibid., p. 95. BW\&Co to Dowson, 29 Sept. 1897, ibid., p. 92; BW\&Co to Roberts, Vallet and Painting, all 30 Sept. 1897, ibid., pp. 99-100. According to WF:P2 Staff Record Book 1879-1902, p. 45, Dowson was employed from October 1897, although he had been working in the laboratories for several months. Cobbett was formally employed from October 1897 and left in January 1898, "As arranged at time of engagement".

${ }^{86}$ BW\&Co to Dowson, 2 Oct. 1897, WF:HSW Letter Books 1897-1898, S/G/148/3, p. 101.

${ }^{87}$ Dowson's response to a complaint, for example, emphasized the precise timing required for successful treatment and the difficulties of comparing antitoxins in the clinical situation. BW\&Co to Waite, 31 Jan. 1897, WF:HSW Letter Books, Dec. 1898 to Jan. 1900, S/G/148/4, p. 94.

${ }^{88}$ There had been considerable discussion about the lease. BW\&Co to Messrs. Markby \& Stewart, several letters, Aug., Sept., and Oct. 1898, WF:HSW Letter Books 1897-1898, S/G/148/3. Undated typescript 'The Wellcome Physiological Research Laboratories', WF: Strong room 6, drawer 1900: Papers re registration of WPRL, 1900-01, henceforward WF:WPRL Registration.

${ }_{89}$ BW\&Co to Dowson at Brockwell Hall, 20 May 1899, WF:HSW Letter Books Dec. 1898 to Jan. 1900, S/G/148/4, p. 541. The previous letter to Dowson, 14 Apr. 1899, ibid., p. 305 had been directed to Charlotte Street.

${ }^{90}$ Chem. \& Drug., 1897, i: 947 . On the opening of the WPRL, ibid., 1899, ii: 780-1. The laboratories are also described in booklets produced by the Company for trade expositions. 
and physiological research, as well as a dark-room and a small library. Initially the stables, compared to the Queen's stables by one journalist, housed fourteen horses, several of which were kept under diphtheria treatment for many years. The published report of the laboratories in the Chemist and Druggist concluded "There can be no doubt that there is a great future before such work as this in connection with the practice of physic, and it is gratifying to know that a firm connected with British pharmacy should be participating in what must be for several years a commerically unprofitable undertaking." 91

The transfer of the WPRL to these larger premises allowed staff expansion. Dowson was joined in the bacteriological laboratory by A. T. Glenny, ${ }^{92}$ one of two schoolboys recruited from the local Alleyn's School, ${ }^{93}$ the other being A. J. Ewins ${ }^{94}$ who joined Dr S. N. Pinkus ${ }^{95}$ in the chemical laboratory. The rest of the staff comprised the bacteriologist $\mathrm{H}$. J. Sudmersen, ${ }^{96}$ a general laboratory assistant, and ancillary workers to look after the animals, prepare the nutritive media, and to bottle and label the sera. Glenny, who remained with the Wellcome laboratories for his entire working life, soon realized that the weekly routine of inoculating the horses with diptheria toxin and bleeding them at irregular intervals was inefficient as the full bleedings were performed weeks, and sometimes months, after the highest antitoxin titres had been reached. Thus he introduced a simple "horse-card" for each animal on which details of all the relevant injections and bleedings could be recorded: this elementary device greatly increased the production of usable antitoxin. ${ }^{97}$

Despite the success of the antitoxins, Wellcome had plans for greater developments, and his concepts of therapeutic advancements emphasized the necessity for the WPRL to be registered under the 1876 Cruelty to Animals Act. The

91 Chem. \& Drug., 1899, 55: 781.

92 C. L Oakley, 'A. T. Glenny (1882-1965)', Biog. Mem. FRS Lond., 1966, 12: 163-80.

93 Alleyn's School arose out of the "Lower School" of Dulwich College: T. L. Ormiston, Dulwich College register 1618-1926, London, Dulwich College, 1925, p. 4. According to Dale, op. cit., note 94 below, Dowson contacted the Headmaster, Dr Baker, about employing boys with a science background. J. F. Thorpe, 'H. B. Baker 1862-1935', Obit. Not. FRS Lond., 1935, 1: 523-6, shows that he was Chemistry Master at Dulwich College until 1902, when he became Headmaster at Alleyn's, although as a Senior Master at the "parent" school he was probably influential in placing promising pupils. Dale to Poynter, 1 Nov. 1960, RS:93HD 65.5, Brockwell Hall, 1952-1967.

94 Ewins worked at the WPRL until 1914, when he joined the staff of the new Medical Research Committee (later Council). In 1917 he moved to May \& Baker and produced M\&B 693, the potent anti-streptococcal agent. See H. H. Dale, 'Arthur James Ewins 1882-1958', Biog. Mem. FRS Lond., 1958, 4: 81-91.

${ }_{95}$ Stanislaus Naftel Pinkus was employed at the WPRL from September 1898, and left 3 December 1901 to go into partnership with Schryver of the WCRL, Dowson being "far from satisfied" with him. BW\&Co to Wellcome, 22 Mar. 1901, WF:HSW Letter Books c. 1901, S/G/148/0, p. 421, memo. 421.

${ }^{96}$ Henry Sudmersen was at the WPRL from 1898-1901 and 1905-25(Staff Record Book, number 1571); he obtained a Ph.D. in Bern in the interim. BW\&Co to Sudmersen, 31 Aug. 1901, WF:HSW Letter Books June to Nov. 1901, S/G/148/6, p. 355; BW\&Co to Sudmersen, 25 July 1905, WF:HSW Letter Books June to Dec. 1905, S/G/148/9, p. 254; Sudmersen to Dowson, 7 Feb. 1905, WF:K. Dowson regarded him as a "particularly clever microscopist": BW\&Co to Wellcome, 22 Mar. 1901, WF:HSW Letter Books c. 1901, S/G/148/0, p. 421, memo. 421; and was delighted to re-employ him. Dowson to Wellcome, 27 Feb. 1905, WF:K.

${ }^{97}$ Op. cit., note 92 above, pp. 163-6. Many of the original "horse-cards" and Glenny's notebooks, including his very first, are in WF/7 ADS Papers and WI/30, Recent Acquisitions: Files of Ehrlich Collection. 


\section{E. M. Tansey}

matter was never entirely dropped after Bokenham's earlier application, ${ }^{98}$ and by 1899 the expense and inconvenience of performing experimental work at other registered premises, especially from the WPRL's location in South London, were becoming obvious. ${ }^{99}$

Publicity for the new laboratories, such as that quoted above from the Chemist and Druggist, attracted attention from anti-vivisectionists who, in turn, alerted the Home Office that serum-testing was being carried out at the WPRL. ${ }^{100}$ At the end of 1899 , Dowson visited the Home Office Inspector, Professor Thane, and freely admitted that such procedures were performed at the WPRL, but he believed that they were not covered by the Act as they were not calculated to give pain. Once more, Home Office staff consulted the previous Legal Opinions and although a Home Office official noted that it "seems morally certain that nothing amounting to illegal infliction of pain takes place in this establishment" Thane was asked to visit "if the Firm will let him do so". 101

Thane acknowledged in his request "that the premises not being registered, I have no right of inspection . . . but I am sure that neither Mr. Wellcome nor yourself wish to conceal your proceedings from the Authorities". ${ }^{102}$ Thus, at the beginning of February 1900 , he inspected the laboratories, outbuildings, and stables and "every room and cupboard in [the] house from roof to cellar". ${ }^{103}$ Dowson was pleased with the way the visit went and advised Wellcome that

According to the Inspector our position is this. The law advisers of the crown have decided that it is permissible under the existing statute to inject animals with substances in order to immunize them in various ways; but that it is not permissible to inject

98 A note in Wellcome's handwriting 'Dr. Dow[son] is now taking up the matter again with Professor Michael Foster', 8 Aug. 1899 WF/180 WPRL. Wellcome was not alone in his assessment of future developments. For example, in July 1895 the Pharmaceutical Society also discussed the need for research laboratories for investigating new drugs (Pharmaceutical Society, Minutes of Committees 5, 24 Mar. 1890-30 Oct. 1914, p. 74), although their laboratories were not registered until 1926. However, Wellcome was probably unique as a pharmaceutical manufacturer in recognizing the need for experimentation and the attendant difficulties.

${ }^{99}$ Undated copy of a letter to Sir Matthew White Ridley (see note 31 above). Appendix B lists 31 substances awaiting investigation, of which only tetanus $\mathrm{C}$ had been tested by Dowson at St Bartholomew's Hospital. Dowson's licence was available there and at the New Museums, Cambridge (HO Returns 1898-1900. In 1897 it had been available in Cambridge only). The impracticality of working in other laboratories is further emphasized in an internal memorandum, 20 July 1900, 'Notes re. petition to HO', probably by Wellcome, WF:WPRL Registration.

100 The Zoophilist, 1 Dec. 1899, reported the opening of the WPRL, taken from Chem. \& Drug., 1899, 55: 780-1, and the Lancet, 1899, ii: 1456-7. After the latter, Wellcome wrote to the Editor, Thomas Wakely, "I very much appreciated your article on my Physiological Laboratories contained in the last issue of the 'Lancet'". WF:C5 HSW Personal 3 1899-1901, p. 172. Members of anti-vivisectionist societies and at least one MP were also prompted to write to the Home Office about the WPRL. HO to Sandman, 6 Apr. 1900; HO to the Honorary Secretary of the International Anti-Vivisection Society, $18 \mathrm{Apr}$. 1900; HO to the Secretary of the London Anti-Vivisection Society, 20 June 1900; HO to Thomas Lough, MP, 2 Aug. 1900. All in PRO HO156/13, pp. 220, 234, 331, 380.

101 HO memo 21 Dec. 1899, by Thane, of Dowson's visit of 16 December 1899; HO Minute, 17 Jan. 1900. Both in PRO. HO 45/11092/B21744/6.

102 Thane to Dowson, 3 Feb. 1900, WF/180 WPRL. After the Chem. \& Drug., article of November 1899 (op. cit., note 91 above), BW\&Co advised Dowson to get an introduction to Thane from either Dr Poore, Sir Michael Foster or Dr Allbutt and "to put a great deal of stress on the work in chemical physiology which is carried on at the Laboratories". BW\&Co to Dowson, 20 Nov. 1899, WF:HSW Letter Books Dec. 1898 to Jan. $1900, \mathrm{~S} / \mathrm{G} / 148 / 4$, p. 864.

${ }^{103}$ Dowson to Wellcome, 7 Feb. 1900, WF/180 WPRL. 
guinea-pigs with the serum from these animals in order to ascertain its antitoxic strength. The latter they regard as an experiment, the former they do not. ${ }^{104}$

Thane's report to the Home Office was as enthusiastic as his predecessor's had been in 1896: "These are excellent laboratories, Chemical and Bacteriological, well arranged and equipped for work of the highest kind". He also reported positively on the stabling facilities for the thirty horses under diphtheria treatment, and the housing for the guinea-pigs used in the testing operations, noting that the only other animals at the WPRL were two goats kept as pets. ${ }^{105}$ His report concluded that many press accounts of the laboratories referred to projected work, for which official sanction would be sought, and that he did not in any way wish to suggest that the laboratories should be prosecuted. However, he admitted that the testing of antitoxins under the 1876 Act was still an open question: he believed that as a matter of fact, although not of legal opinion, diphtheria antitoxins did not cause pain and did not therefore come under the Act. However, the Law Officers' Opinion of 1896 was used in interpreting the law, and therefore production of antitoxins could continue quite legally at Brockwell Hall, but testing and standardization were still to be performed on other, registered, premises.

\section{THE APPLICATION FOR REGISTRATION, 1900}

In February 1900, Wellcome again petitioned the Secretary of State for the Home Department, Sir Matthew White Ridley, for the registration of the WPRL. ${ }^{106} \mathrm{He}$ presented clear scientific and economic reasons for his application, detailing the outstanding facilities of the laboratories, and stressing the importance of drug standardization and the urgent need for experimental physiological techniques to achieve the level of reliability of some imported pharmaceutical products. In particular, the development and evaluation of new therapies, especially those associated with animal products, demanded physiological experimentation and quantification. ${ }^{107}$ The introduction of large numbers of useless therapeutic novelties into Britain could be avoided if proper physiological analysis and testing was introduced.

It is not going too far to assert that the administration of all powerful remedies to human beings should first of all have a sound basis in laboratory experiment. This remark applies equally to that class of remedies in which the relation between the chemical constitution and physiological action might permit modifications to be introduced with the result that their usefulness would be greatly enhanced, as to new therapeutic agents which are from time to time being discovered in the field of nature and in the chemical laboratory. ${ }^{108}$

${ }^{104}$ Notes made by Dowson, 7 Feb. 1900, ibid.

${ }_{105}$ HO memo, 9 Feb. 1900, by Thane, of visit to the WPRL. PRO HO45/11092/B21744/6.

106 Undated petition to Sir Matthew White Ridley, WF:WPRL Registration.

${ }^{107}$ HO to Dowson, 16 and 23 Feb., 13 and 15 March 1900, WF:WPRL Registration. Some of Wellcome's arguments were shared by American Companies. See J. M. Liebenau, 'Scientific ambitions: the pharmaceutical industry 1900-1920', Pharm. in Hist., 1985, 27: 3-11. The legal context within which Wellcome worked, however, was substantially different.

${ }^{108}$ Typescript draft, 'The Wellcome Physiological Research Laboratories', undated, WF:WPRL Registration. Wellcome's opinions pre-date the passing of the Therapeutic Substances Act (1925), 15 \& 16 Geo.V, c. 60, which imposed some standardization on a specified range of products. 


\section{E. M. Tansey}

He further maintained "that medical science is entering upon an advanced phase in which clearly recognised disease conditions are to be met by the administration in various ways of remedies with definite determined properties in exact doses." 109

Coupled with these scientific justifications was the businessman's argument that the manufacture of fine medical-chemical products in Britain had been severely limited by the lack of precise physiological testing. "This", Wellcome concluded, "with all it involves in loss of trade, loss of employment to the citizens of this country in a field where they could excel, and loss of prestige is all the more serious because it is unnecessary." Similar arguments had been developed in the pharmaceutical press. The Chemist and Druggist, in noting German provisions for industry, lamented that

With such enterprise and with such scientific resources at command it is not surprising that in the production of fine chemicals British manufacturers have been to a large extent beaten out of the field. English discoveries of great practical value have, indeed, been carried off and utilised by Germans right under our noses.

Their recommendation that Britain needed "firms willing to risk ten, twenty or thirty thousand pounds annually on what might be unprofitable research" ignored the existing legal constraints. ${ }^{110}$

Wellcome's financial ability and willingness to promote such research was also subject to the additional restrictions of the 1876 Act, and his application for registration painstakingly distinguished his commercial operations from the research ventures that he supported, although this seems to contradict some of his previous assertions. ${ }^{111}$

These laboratories are entirely separate and distinct from the works and business departments of Burroughs, Wellcome and Company. They are under independent direction and are conducted as strictly professional institutions. They are not carried on as a source of profit but are maintained at a heavy cost by funds derived from other sources, and like the Wellcome Chemical Research Laboratories (6 King Street, Snow Hill, London E.C.) have been designed and equipped for research work. At the present time, however, this research work is fettered and hindered by the inability to carry out necessary physiological experiments. ${ }^{112}$

This distinction, of the laboratories from the commercial company, was not as clear as Wellcome seems to have believed and was certainly questioned by many of his critics in the medical profession. Indeed, Dowson checked and tested Company products, ranging from experimental therapeutics to everyday commodities; ${ }^{113}$ was frequently asked, as stipulated in his contract, to advise on Company matters; and was, like all the laboratory

\footnotetext{
109 Ibid.; Chem. \& Drug., 1896, 49: 121-2.

${ }^{110}$ Ibid. An analysis of German research at this time may be found in J. J. Beer, The emergence of the German dye industry, Urbana, University of Illinois Press, 1959, especially chapter 8, 'The rise of the industrial research laboratory', pp. 70-93.

${ }^{111}$ Similar confusion arose between Wellcome's business and his museums. See H. J. M. Symons, op. cit., note 6 above, p. 4 .

112 Typescript, op. cit., note 108 above.

113 See, e.g., BW\&Co to Dowson, 4 Apr. 1900 (on thyroid glands), WF:HSW Letter Books 1900, S/G/148/5, p. 529; BW\&Co to Dowson, 1 Feb. 1901 (on beef juice), WF:HSW Letter Books $c$. 1901, $\mathrm{S} / \mathrm{G} / 148 / 0$, p. 36. He also pursued research on shallow burial: see L. J. Picton, Thoughts on feeding, London, Faber \& Faber, 1946, pp. 17-9.
} 
staff, employed by the Company. ${ }^{114}$ And after all, the raising of diphtheria antitoxin for sale by the Company had been the raison d'etre for the WPRL. Wellcome consistently stressed that the serum was sold below cost price, and seems to have equated the absence of profit with divorce from commerce.

Widespread prejudice against his "trade" associations became manifest when he and his staff attempted to rally both direct and indirect support for the registration application. ${ }^{115}$ Initially a copy of Wellcome's petition was sent to several prominent medical men, asking for their support "As the subject is one of practical importance to the medical profession and to the public". 116 The intention was to approach thirty-five individuals and four organizations. ${ }^{17}$ The canvassing was unequally divided between Wellcome himself, ${ }^{118}$ staff from the Snow Hill headquarters, notably J. C. Smith, ${ }^{119}$ and Walter Dowson. ${ }^{120}$ Influential non-medical support was also sought from A. J. Balfour and Lord Rosebery, although both declined to sign the petition. ${ }^{121}$

The original application was laid before the Home Department on 15 February

${ }^{114}$ For details of his employment see notes 76 and 85 above. The use of "commercial contracts" for scientific staff was to prove irksome. Dowson was expected to make reports to BW\&Co on WPRL staff, e.g. BW\&Co to Dowson, 9 Jan. 1900, WF:HSW Letter Books 1900 S/G/148/5, p. 22; and BW\&Co staff, usually J. C. Smith, made regular visits to the WPRL, e.g. BW\&Co to Dowson, 21 Nov. 1900, WF:HSW Letter Books 1900-1901, S/G/148/1, p. 461.

115 Typescript draft, op. cit., note 108 above. BW\&Co donated medical equipment to the city of London Volunteers going to the Boer War: Chem. \& Drug., 1900, 56: 48; and prominently advertised WPRL sera at trade exhibitions, e.g., ibid., 1901, 58: 441. Sub-letting ground at Brockwell Hall was considered as a means to gain local support; BW\&Co to Wellcome, WF:HSW Letter Books 1900-1901, S/G/148/1, p. 959, memo. 245.

${ }^{116}$ Dowson to BW\&Co, 31 Jan. 1900, enclosing a copy of the petition to the $\mathrm{HO}$ and the letter addressed to medical men, WF:WPRL Registration.

${ }_{117}$ The list accompanying the documents referred to in the above note includes the names of Sir John Burdon Sanderson, Regius Professor of Medicine, Oxford; Francis Gotch, Professor of Physiology, Oxford; W. S. Church, President of the Royal College of Physicians; E. A. Schäfer, Professor of Physiology in Edinburgh; and Sir Michael Foster, Professor of Physiology, Cambridge. All would ultimately sign Wellcome's petition. The name of "Mrs. Garrett Anderson, M.D." is listed but crossed out. The Societies listed are the Incorporated Society of Medical Officers of Health; the Society for the Advancement of Medicine by Research (sic), the Pharmaceutical Society and the Society of the Chemical Industry, WF:WPRL Registration.

118 Wellcome obtained the support of the Lancet's Editor, Thomas Wakley. Wellcome to BW\&Co, 16 Feb. 1900, WF:WPRL Registration.

119 J. C. Smith sought support from J. Ward Cousins, President of the BMA, telegram Burcome (BW\&Co) to Wellcome, 20 Feb. 1900; Sir Thomas Clifford Allbutt, Allbutt to BW\&Co, $26 \mathrm{Feb}$. 1900; Mr Sandemann, Chairman of the London Chamber of Commerce, BW\&Co to Dowson, 2 Mar. 1900; E. M. Holmes, President of the British Pharmaceutical Conference 1900, Holmes to BW\&Co, 1 and 3 Mar. 1900. All in WF:WPRL Registration. Ward Cousins, Allbutt, and Holmes signed the petition (Haggis, op. cit., note 5 above, pp. 343-4); Smith accepted that they signed as private individuals, not for their respective organizations, e.g. BW\&Co to Holmes, 2 Mar. 1900, WF:HSW Letter Books 1900, S/G/148/5, p. 246.

120 Dowson approached Dawson Williams, Editor of the British Medical Journal; and E. C. Seaton, President of the Council of the Incorporated Society of Medical Officers of Health (Dowson to BW\&Co, 23 Feb. 1900); Lord Avebury, Chairman of the Associated Chamber of Commerce (BW\&Co to Dowson, 2 Mar. 1900); Victor Horsley (BW\&Co to Dowson, 9 Mar. 1900; Dowson to BW\&Co, 11 Mar. 1900. All in WF:WPRL Registration.) Dawson Williams, Seaton, and Horsley signed the petition: Haggis, op. cit., note 5 above. p. 344.

${ }_{121}$ Both were articulate proponents of technical education. A. J. Balfour, later Prime Minister (from July 1902 to December 1905), had "every sympathy with the objects you have in view" but felt unable to sign a memorial addressed to a colleague: Balfour to Dowson, 20 Feb. 1900. Lord Rosebery had been Parliamentary Under-Secretary at the Home Office (1881-3). He refused to sign, claiming to have no influence: Rosebery to Dowson, 19 Feb. 1900. WF:WPRL Registration. 


\section{E. M. Tansey}

1900; Dowson forwarded additional signatures the following month. ${ }^{122}$ Eighteen prominent doctors finally supported Wellcome; not all those approached had felt able to sign. ${ }^{123}$ Sir Dyce Duckworth, Honorary Physician to the Prince of Wales, and Treasurer of the Royal College of Physicians and its representative on the General Medical Council, ${ }^{124}$ felt that the restrictions and difficulties placed on "Professors and Teachers in our great Schools of Medicine and Universities" were almost insuperable and that it was therefore unreasonable to request additional facilities for "firms engaged in business" although he recognized that Burroughs Wellcome and Co. did excellent work. He also raised the question that would recur throughout the period of Wellcome's application - if the Home Secretary did register the WPRL, the privilege could not then be withheld from other, "inferior" firms. ${ }^{125}$ Dowson received this opinion with considerable dismay and immediately refuted some of the objections: "my own feeling is, and this was the point which weighed with those who have already signed, that the principle of the thing is right, and that results would be good both for the medical profesion and for the public." He argued that those who would benefit most from the registration of the WPRL and other "commercial" laboratories would be the sufferers from disease, "not to mention the advantages which must accrue to the science of a very difficult subject". 126

Within the Wellcome organization, it was thought that the application would go before the Home Secretary himself who would then pass it to the Law Officers of the Crown or to the Association for the Advancement of Medicine by Research (AAMR). Dowson knew that the latter had been approached when the Clinical Society requested registration, but there is no record that they were involved with the Wellcome application, and in view of its generally facilitatory role and the fact that many of its members had signed Wellcome's petition, it seems unlikely that its opinion was canvassed. ${ }^{127}$

In May 1900, Dowson's contract was extended for three years, and he was provided with a letter of indemnity, approved by the Company's legal advisers, in which "[we] recognise our obligations to you in all such work performed in our Laboratories ... . and we undertake to pay any fines, expenses, and any other fit and

122 Dowson to Ridley, 15 and 22 Feb. 1900, both in PRO HO45/1 1092/B21744/8; HO to Dowson, 16 and 23 Feb. 1900, 13 and 15 Mar. 1900, all in WF:WPRL Registration.

${ }_{123}$ In addition to those mentioned in notes 117 to 120 above, supporters were C. M. Chadwick, Professor of Materia Medica, Pharmacology \& Therapeutics, Yorkshire College, Leeds; Julius Dreschfield, Professor of Medicine, Victoria University, Manchester; Ray Lankester, Professor of Physiology and Comparative Anatomy, Royal Institution; Lord Lister, President of the Royal Society; E. H. Starling, Professor of Physiology, University College London; G. Sims Woodhead, Professor of Pathology, Cambridge; and J. W. Moore, President of the Royal College of Physicians of Ireland: Haggis, op. cit., note 5 above, pp. 344-5. Sir Michael Foster was closely involved in drafting suitable replies to the Home Office and had publicly praised "Wellcome \& Burroughs" (sic), Chem. \& Drug., 1899, 54: 796.

124 Munk's Roll, 1926, 4: 179-80; and DNB.

125 Duckworth to Dowson, 12 Feb. 1900, WF/180 WPRL.

126 Dowson to Duckworth, 24 Feb. 1900, WF/180 WPRL. There is nothing to suggest that Duckworth was swayed by this appeal, and an obituary commented that he "always rather mistrusted the laboratory": Lancet, 1928, i: 210-1.

${ }^{127}$ BW\&Co to Wellcome, 17 Feb. 1900, WF:HSW Letter Books 1900, S/G/148/5, p. 192, memo. 211. For the role of the AAMR see French, op. cit., note 3 above, pp. 177-219; and Vine, op. cit., note 22 above, pp. 10-1. The AAMR Minutes Books for this period have not been located. 


\section{The Wellcome Physiological Laboratories}

proper charges which may be incurred by you in connection with such work ...". The accompanying contract specified that, because of this letter, all Dowson's work should be strictly subject to the Company's sanction and all scientific communications should likewise have the direct approval of Wellcome himself or his company representatives. $^{128}$

\section{THE RESPONSE OF THE HOME OFFICE AND THE ROLE OF THE ROYAL COLLEGES}

Wellcome's application was immediately referred to Professor Thane, who agreed that drug standardization was of considerable importance, but expressed doubts about permitting one firm to perform the work as this would undoubtedly confer a commercial advantage. He suggested that three questions be addressed to the Royal Colleges of Surgeons and of Physicians, and that the second and third also be put before the Pharmaceutical Society, admittedly "an association of tradesmen", but one nevertheless affected by the application. ${ }^{129}$ The Home Secretary acted upon this advice, and asked

1. Is the standardisation of drugs by means of experiments on animals indispensable in the public interest?

2. If so, is it probable that, in proper cases, duly-qualified experimenters working in the premises of manufacturing chemists should be empowered to perform the necessary experiments on animals for this purpose?

3. If it is not thought desirable that manufacturing chemists should be entrusted with this power, what other provision is it advisable and practicable to make for the purpose? ${ }^{130}$

The Council of the Pharmaceutical Society promptly replied that they did not consider it desirable that experimental work be carried out in commercial laboratories, and suggested that the existing arrangements between Parke Davis and Company and the Conjoint Laboratories could be extended to other manufacturers. ${ }^{131}$ Both Royal Colleges referred the questions to their joint Laboratories Committee, ${ }^{132}$ although the private correspondence of W. S. Church, President of the Royal College of Physicians, with Digby of the Home Office, indicates his opposition to the registration of a commercial laboratory, although he had signed Wellcome's petition earlier in the year.

128 BW\&Co to Wellcome, 27 Apr. 1900, WF:HSW Letter Books 1900, S/G/148/5, p. 547; BW\&Co to Dowson, 22 May 1900, ibid., p. 668; BW\&Co to Dowson, 22 May 1900, ibid., p. 662. It was only after registration that papers openly acknowledged the WPRL. Bokenham, for example, always published as a 'Late Research Scholar, British Medical Association', and credited BW\&Co in his texts, but never in his title: e.g. Br. med. J., 1895, ii: 416; ibid., 1896, ii: 3-4; ibid., 1897, ii: 1277-8. Whether such reticence was associated with the difficulties with the Home Office is not known.

${ }^{129}$ HO Minute and draft by Thane, 11 Mar. 1900, PRO HO45/1 1092/B21744/8. He discussed establishing an independent testing station with the Pharmaceutical Society and the RCS.

${ }^{130}$ Home Secretary to RCS, 30 Apr. 1900, Minutes of Council RCS, 1899-1901, p. 190. In 1900 the RCS celebrated its centenary, and an article by V. Plarr, 'The centenary of the Royal College of Surgeons of England', Nature, 1900, 62: 294-6, emphasized its role in the development of science, and as a guardian of medical ethics.

${ }^{131}$ Pharmaceutical Society to HO, 10 May 1900, PRO HO45/1 1092/B21744/16, enclosing an advertisment placed by Parke, Davis \& Co. in Br. med. J., 1900, i: 88.

132 The laboratories were managed by a Committee representing both Colleges and in 1900 consisted of Dr Pye-Smith (Chairman), Drs W. D. Halliburton and S. Martin (from the RCP) and Sir William MacCormac, H. G. Howse and H. Morris (from the RCS). Minutes of Council, RCS, 1899-1901, p. 164. 


\section{E. M. Tansey}

Church also raised the possibility of either the Conjoint Laboratories or the Jenner Institute becoming Official Testing Stations, although he stressed that pecuniary assistance would be necessary. ${ }^{133}$

The Laboratories Committee reported in July 1900. While supporting the need for some animal experimentation for drug standardization, it regarded "the authorisation of the necessary experiments in the premises of manufacturing chemists as highly undesirable". ${ }^{134}$ Perhaps not too surprisingly, the Committee praised the work of the Royal Colleges, which in the public interest and without financial advantage had for many years produced and tested serum at stables made available by the Metropolitan Asylums Board and funded by the Goldsmiths Company. ${ }^{135}$ It explained the existing provision of a Testing Service for other manufacturers' serum, and suggested that such "independent" validation was more authoritative than any performed by the manufacturers themselves. ${ }^{136}$ This arrangement was already working well with Parke Davis and Company. ${ }^{137}$

These reports came to Wellcome's attention and he realized that the Home Office would require additional reasons before granting registration. ${ }^{138} \mathrm{~A}$ draft document prepared by the Wellcome organization emphasizes that the work undertaken at the WPRL should not be misunderstood. "Research work is not a thing which can be made to pay and these departments are carried on as strictly ethical institutions quite distinct from manufacturing departments." ${ }^{139}$ Perhaps to highlight this point, the Company sought press coverage of the work of the WCRL, which had actually moved to new premises some months previously. The resulting reports, which fortuitously praised the scientific quality of the work and the professional standards of the staff, and lauded "Mr. Wellcome's public spirit", also emphasized the independence of these laboratories from the Company: "the clovenhoof of commercialism has not appeared in Mr. Wellcome's scheme". ${ }^{140}$

A concerted effort was now made to achieve registration: staff of both the WPRL and the WCRL were asked to submit ideas for a new petition and Fletcher Moulton's

133 Church to Digby, 7 May 1900; Digby to Church, 12 May 1900; Church to Digby, 13 May 1900. All in PRO HO45/11092/B21744/15.

${ }_{134}$ Report of the Laboratories Committee, Minutes of Council, RCS 1899-1901, 3 July 1900, pp. 221-3. See also the Lancet, 1900, ii: 338, and note 150 below.

${ }_{135}$ Minutes of Council, RCS 1893-1895, 8 Mar. 1895, pp. 354-6.

${ }^{136}$ Minutes of Council, RCS 1897-1899, 10 Mar. 1899, p. 308. The fee depended on the strength of the serum.

${ }^{137}$ E.g., Minutes of Council, RCS 1899-1901, 5 Oct. 1899, p. 61. See also Chem. \& Drug., 1898, 53: 182-3; ibid., 1899, 54: 896. Both articles praise Parke Davis \& Co.'s physiological testing (although products other than serum were tested in America). Three years later a similarly laudatory report did recognize the difficulties facing British manufacturers: "Physiological tests made in this country by pharmacists would, I presume, infringe the Vivisection Act"; ibid., 1902, 61: 892.

${ }^{138}$ On receiving the Laboratories Committe report, the Home Secretary decided to reject the WPRL's application and appropriate letters to Wellcome, the Royal Colleges and the Pharmaceutical Society were prepared. All in PRO HO45/11092/B21744/20. Dowson's visit of 27 July 1900 prevented these being sent. See note 144 below.

139 'Notes re. petition to HO', typescript, probably by Wellcome, dated 20 July 1900, WF:WPRL Registration.

${ }_{140}$ BW\&Co to Editor, Pall Mall Gazette and other newspapers, 4 July 1900, WF:HSW Letter Books $c$. 1901, S/G/148/0, p. 871; Brit. \& Col. Drug., 1900, 37: 751-2; Pharmaceut. J., 1900, 64: 676-7; and Chem. \& Drug., 1900, 56: 1028-9. 
legal advice was sought once again. ${ }^{141}$ Dowson was dispatched for an informal talk with Professor Thane at University College, with instructions to withdraw the petition rather than risk an outright rejection, if that seemed the likely outcome. ${ }^{142}$ This visit was to prove of critical importance as Dowson realized "that a crisis was on us" and after appealing to Thane "as one scientific man to another", he learnt that a formal letter of refusal was about to be sent to Wellcome from the Home Office. Dowson sped to the Whitehall office of Sir Kenelm Digby, and after a lengthy discussion during which he extracted the admission that the Wellcome petition "was one of the more important and one of the most difficult to deal with that they had before them for years", he finally persuaded Digby not to send the letter and to allow Wellcome more time to supplement his petition. ${ }^{143}$

An even more significant outcome of this visit was Dowson's declaration of readiness to testify that the diphtheria antitoxin testing procedures were painless, if legal proceedings were taken against him. Digby recorded that "Dr Dowson has thrown down a distinct challenge to the Home Office to test this, and I cannot blame him for doing so. It seems to me a perfectly open and straightforward course to take." ${ }^{144}$ However, as Digby wrote, it would pose several problems for the Home Office: proceedings could indeed be initiated, but it seemed unlikely that the prosecution would be successful, particularly as Thane was not prepared to argue that such procedures were painful. A failed prosecution would open the Home Office to complaints from anti-vivisection groups that they had not been consulted, and such conflict should be avoided if possible. The Secretary of State could once more refer to the Law Officers and ask for specific advice about a prosecution. Alternatively, if the matter was now too important for the Home Office alone, a strong inter-departmental committee should be established to consider the broader issues of scientific advances and their commercial applications, and non-scientific men, including opponents of animal experimentation, should be invited to participate. ${ }^{145}$

Meanwhile Dowson's report to Wellcome listed the fundamental quetions raised by the Home Office:

1. Why could Dowson not do the required work at St Bartholomew's or the Conjoint Laboratories? ${ }^{146}$

2. Could the Royal Colleges provide all the necessary facilities and if so, would they? 147

3. Would Wellcome gain a valuable monopoly if the Home Office granted this petition?

${ }^{141}$ BW\&Co to Moulton, 24 July 1900, WF/180 WPRL.

142 BW\&Co to Dowson, 27 July 1900, WF:HSW Letter Books 1900, S/G/148/5, p. 952.

143 Dowson to Wellcome, 27 July 1900, WF/180 WPRL.

144 HO memo by Digby, 30 July 1900, about Dowson's visit of 27 July 1900. PRO HO45/1 1092/B21744/20.

145 Ibid.

146 Dowson's licence was available at St Bartholomew's but not at the Conjoint Laboratories. See note 99 above for more details.

${ }^{147}$ The Conjoint Laboratories did have facilities but were extending their own serum production: see note 149 below. 
4. How many other manufacturers would request the same privileges? ${ }^{148}$

5. Would the granting of registration confer an indirect guarantee of Wellcome's product?

6. Why could not all the serums be tested at the Conjoint Laboratories? ${ }^{149}$

Dowson had gleaned useful information from his informal meetings. The Home Office would only act positively if the medical profession fully and publicly supported Wellcome, and as articles in the medical press a few weeks later indicated, this was not so. ${ }^{150}$ The Chemist and Druggist, reporting a speech of Dr Church ${ }^{151}$ at a dinner of the Pharmaceutical Society, commented that it was an open secret that the Society opposed Wellcome's application and now that the Laboratories Committee was of the same opinion, it boded ill for manufacturers. If the Home Secretary acted on the recommendations and refused registration, then the raising and standardization of antitoxins would be substantially handicapped. ${ }^{152}$

Wellcome's response to this barrage of new information was immediate: he wrote to the Home Office formally asking for more time to supplement his petition, ${ }^{153}$ and he initiated enquiries both at home and abroad in search of additional support and information.

\section{THE CAMPAIGN FOR FURTHER SUPPORT}

Wellcome's overseas agents indicated that legal curtailment of medical research was unknown elsewhere and in particular praised the German policy of encouraging technical education and research. ${ }^{154}$ Enquiries in Italy, France, and Switzerland about animal experimentation ${ }^{155}$ and legal requirements for drug, serum and

\footnotetext{
${ }^{148}$ As discussed below, questions 3 and 4 seem contradictory. The Home Office was concerned not to set a precedent for other companies by registering the WPRL, but at the same time did not want to provide Wellcome with a virtual monopoly.

149 J. C. Smith reported to BW\&Co that the Conjoint Laboratories' expansion at Balham might be to provide a Government Testing Station for serum, BW\&Co to Wellcome, 25 Jan 1901, WF:HSW Letter Books c. 1901, S/G/148/1, p. 958, memo. 242. This did not occur, but the additional stabling achieved HO registration without debate: HO Returns, 1903.

${ }^{150}$ Lancet, op. cit., note 134 above; Chem. \& Drug., 1900, 57: 283-4; Br. med. J., 1900, ii: 447-8. Wellcome believed the Lancet report to be the most accurate account of the Committee meeting, but a comparison of all three with the Committee report shows that of the British Medical Journal to be closest.

151 Chem. \& Drug., 1900, 56: 838-9.

152 Dowson believed that the Royal College of Physicians (RCP) was interested in extending the law and that the RSC was more hostile: Dowson to BW\&Co, 27 July 1900, WF/180 WPRL. Ironically, 30 years later Wellcome achieved the distinction, rare for a non-medical person, of election as a Fellow of the College. WF: C4 WE:HSW/Societies/R C Surg.; Plarr's Lives, (1930-51), pp. 831-3. The relevant documents have not been located in the Archives of the Pharmaceutical Society; I thank their Archivist, Miss K. Arnold-Foster, for her assistance.

${ }_{153}$ HSW to HO, 30 July 1900 . The extension was readily granted: HO to Wellcome, 3 Aug. 1900, WF/180 WPRL.

154 Ulan to Wellcome, 21 July 1900; Linkenheil \& Co., Berlin to BW\&Co, 23 Aug. 1900, WF:WPRL Registration. The German company Bayer A.G. established research laboratories in the 1860s and employed professional scientists without restricting their work. G. Meyer-Thurow, 'The industrialization of invention: a case study from the German chemical industry', Isis, 1982, 73: 363-81.

${ }^{155}$ Raffo Dalmazzo \& Co. to BW\&Co, 13 and 28 Aug. 1900. No law applied in Italy, "whatever is required" being allowed; 'Harry' in Paris to BW\&Co, 23 Aug. 1900, reported "There is of course a general law against cruelty to animals, but this is never put into action in the case of experiments made with an object of public utility"; J. G. Jeffcoat (Export \& Commission Agent) to BW\&Co, 24 May 1900; 'Harry' to BW\&Co, 29 Aug. 1900; Institut Pasteur to BW\&Co, 20 Nov. 1900; Auguste Aman, Lausanne to BW\&Co,
} 
chemical standardization ${ }^{156}$ also revealed no restrictions. In America there were relevant statutes about the cruelty to animals only in the states of Massachusetts and Washington, although there were no specific provisions against scientific work. ${ }^{157}$

It is worth considering whether prejudice existed against Wellcome, not just as a "tradesman", but as an American. Although Wellcome was a prominent member of the American Society of London, and there had been an earlier suggestion that Burroughs Wellcome and Co. had been subject to nationalist prejudices, Wellcome himself stoutly maintained, "I have never had reason to feel myself either a stranger or a foreigner in this country". No evidence has been found amongst Home Office, or any other, records that Wellcome was discriminated against as a foreigner (although see below on the comments expressed in 1905), and contemporary accounts of American business activities were usually favourable. Lord Rosebery, for example, used a particularly apt analogy: "In these days we need to be inoculated with some of the nervous energy of the Americans". ${ }^{158}$ What was of concern in Britain at this time were the activities of the various anti-vivisectionist movements and Wellcome had been especially annoyed at the way his Company's policy of cheap serum had been cynically disparaged in the Abolitionist. ${ }^{159}$ This attack was particularly inopportune as it occurred whilst the registration petition was under Home Office consideration. However, Dowson's Whitehall contacts advised him that they were actually more afraid of repeating the "Coal-Tar Industry mistake", 160 a reference to the decline of that industry despite its calls for Government support. Wellcome's staff considered several ways in which their case for registration of the laboratories could be advanced. One plan was to issue explanatory booklets to all medical practitioners in Britain: eventually, more discreet advertising methods were employed. ${ }^{161}$

17 Sept. 1900. All in WF:WPRL Registration. BW\&Co also wrote (13 Aug. 1900) to its Austrian and Belgian agents, but there is no record of replies: WF:HSW Letter Books 1900-1901, S/G/148/1, p. 20.

156 BW\&Co to the agents listed in notes 154 and 155 above, 2 Oct. 1900, ibid., pp. 245, 247-50.

157 Cody to Power, 23 Aug. 1900; Power to BW\&Co, 24 Aug. 1900, WF:WPRL Registration; BW\&Co to Power, 11 Aug. 1900; WF: Letter Books 1900-1901, S/G/148/1, p. 18.

158 'Mr. Wellcome does not complain of British injustice', Chem \& Drug., 1896, 48: 63; Lord Rosebery (see note 121 above) The Times, 16 Oct. 1901, quoted and discussed in R. H. Heindel, The American impact on Great Britain 1898-1914, Philadelphia, University of Pennsylvania Press, 1940, p. 215. See also J. H. Dunning, American investment in British manufacturing industry, London, George Allen \& Unwin, 1958, pp. 62-3.

${ }^{159}$ Wellcome to BW\&Co, 11 Sept. 1900, WF:WPRL Registration; Abolitionist, 15 Aug. 1900, p. 1. Wellcome was a Life Member and Vice-President of the Research Defence Society (RDS): RDS Quarterly Report, 1913. In 1980, the Wellcome Foundation (successor to BW\&Co) were, with Glaxo and ICI, the first Company Members of the RDS. Information courtesy of The Council of the RDS. In its campaign for support, BW\&Co had been especially careful not to attract anti-vivisectionist attention: BW\&Co to Dowson, 3 Mar. 1900, WF: Letter Books 1900-1901, S/G/148/5, p. 259. See also note 100 above.

${ }^{160}$ Op. cit., note 143 above. See, e.g., R. Meldola, 'The scientific development of the coal-tar industry' (1886), reprinted in W. M. Gardner (editor), The British coal tar industry; its origin, development and decline, London, Williams \& Newgate, 1915, pp. 121-40. Another writer noted, "the coal industry has given birth during recent years to several important daughter industries ... the most important is the manufacture of synthetic medicinal preparations, which . . . bids fair to revolutionise medical science": A. G. Green, 'The relative progress of the coal-tar industry in England and Germany during the past fifteen years' (1901), reprinted in ibid., pp. 189-203. Concern was frequently expressed in the pharmaceutical press about the low status of British science, particularly when compared with Germany, e.g. Chem. \& Drug., 1896, 48: 78-9.

${ }^{161}$ E.g., BW\&Co to Dowson, 19 Oct 1900, WF:HSW Letter Books 1900-1901, S/G/148/1, p. 310. 


\section{E. M. Tansey}

The Home Office had, of course, taken considerable notice of the opinions expressed by the two Royal Colleges. Dowson's private informants, as well as Fletcher Moulton, suggested that approaches should be made to all members of the Laboratories Committee, "in the hope of converting them from their conservative opinions, as probably their conversion means to us success or failure in this petition."162 Thus Dowson began to visit and correspond with several prominent doctors and members of the Laboratories Committee; and his confidential notes to the Company ${ }^{163}$ and subsequent report to Wellcome ${ }^{164}$ indicate not only the extent of his canvassing but also the range of opposition that the WPRL faced from the medical authorities.

The Chairman of the Laboratories Committee, Dr P. H. Pye-Smith, was initially reluctant even to discuss the problem, claiming that "It is an official matter entirely". He relented eventually but argued that the precedent of the WPRL's registration would result in the granting of similar applications with no guarantee as to the quality of staff or facilities. The only retort that seemed to influence him was Dowson's reminder that licence and certificate applications had to be supported by responsible members of the profession. At the end of the interview he promised that "he would do what he could". 165

The other member of the Laboratories Committee interviewed by Dowson, Dr Sidney Martin, was in "most decided and fixed opposition to Mr. W's desire", and although he expressed satisfaction with the work of the WPRL, he too believed that the Home Office might proceed to register inferior laboratories. The argument that Dowson had used so convincingly with Pye-Smith failed to satisfy Martin, who cited Bokenham as a conspicuous example of the failure to maintain standards. ${ }^{166}$ Martin also doubted the independence of laboratories associated, however tenuously, with a commercial company, and he challenged Dowson to say whether, if a new method of precipitating and drying antitoxins was discovered in the WPRL laboratories, it would be published immediately. When Dowson replied "no", Martin re-emphasized his opposition to the registration of any but a purely scientific institution. He thought that it would be some time before such laboratories as the WPRL would be registered, although he also believed that the Home Office would not interfere with their present production of antitoxin. ${ }^{167}$

The Director of the Conjoint Laboratories, T. G. Brodie, while friendly towards the WPRL, was concerned that "We medical men must take care that experimental science, especially biological science, is not made subservient to commercial

162 J. C. Smith's notes of an interview with Chune Fletcher and Fletcher Moulton, 20 Dec. 1900, WF:WPRL Registration.

${ }^{163}$ BW\&Co to Wellcome, 11 Jan. 1901. WF:HSW Letter Books 1900-1901, S/G/148/1, p. 859, memo. 182. In Wellcome's writing at the side of this assertion, "Noted but do not be discouraged right will prevail".

${ }^{164}$ Notes from Dowson to BW\&Co, 25 Jan. 1901, WF/180 WPRL.

165 Ibid., notes of an interview, 28 Dec. 1900 with "A", i.e. Dr P. H. Pye-Smith, Chairman of the Laboratories Committee and prominent member of the RCP to whom Dowson had been introduced by Allbutt, BW\&Co to Wellcome, 31 Dec. 1900, WF: Letter Books 1900-1901, S/G/148/1, p. 743, memo. 100.

${ }^{166}$ Martin does not seem to have realized that it was because Wellcome wished to be seen to be within the law that he was applying for registration.

${ }^{167}$ Op. cit., notes 163 and 164 above. Notes of a long interview with "G" (Dr Sidney Martin), 8 Jan. 1901, at which time he was Professor of Pathology at UCL. 
interests", and was anxious to know how testing experiments were done at the unregistered premises of the WPRL. Dowson replied that such experiments did not give pain and were therefore outside the 1876 Act. Although Brodie agreed, he warned that many other physiologists did not, and that Martin, in particular, believed strongly that such work was painful and should come under the 1876 Act. Brodie already knew that the Home Office had written to several leading bacteriologists about this, and Dowson warned the Company that a directive might therefore be expected any day from the Home Office, stopping such work at the WPRL. ${ }^{168}$ Wellcome's handwritten comment at the side of this report is emphatic: "I shall seriously consider the question of establishing physiological testing laboratories abroad if we finally fail to get justice at home." 169

The wariness of "commercial links", expressed by Pye-Smith, Martin, and Brodie, was repeated by Frederick Hewitt ${ }^{170}$ but Dowson's other contacts supported the application. Anthony Bowlby was "frankly on the side of the WPRL all along the line"; ${ }^{171}$ Dr Frederick Andrewes's response was, "you have not to convert me in this matter"; 172 and Dr Stewart was "entirely on the side of the WPRL". ${ }^{173}$ Frederick Gowland Hopkins actually indicated that had Dowson, rather than Wellcome, applied for registration, the commercial associations would have been obviated, and the procedure would have been easier. ${ }^{174}$

Wellcome's "trade" associations were simultaneously causing problems with the British Medical Journal. Its Business Manager refused to provide offprints of papers by members of the WCRL, as he considered them to be commercial advertisements.

\footnotetext{
${ }^{168}$ Op. cit., notes 163 and 164 above. Notes of an interview, 4 Jan. 1901, with "F”, Dr T. R. Brodie, who objected that other firms would demand the same privilege if the WPRL were registered.

169 BW\&Co to Dowson, 25 Jan. 1901, WF:HSW Letter Books 1900-1901, S/G/148/1, p. 966; BW\&Co to Wellcome, 1 Mar. 1901, suggests moving to Milan, WF: Letter Books c. 1900, S/G/148/0, p. 253, memo. 341 .

${ }^{170}$ Op. cit., note 164 above. Notes of an interview, 9 Jan. 1901, with "H”, Dr Frederick Hewitt, “a very old friend and now eminent in the medical world". Knighted in 1911, he became anaesthetist to Edward VII. Lancet, 1916, i: 157-61.

${ }^{171}$ Op. cit., note 164 above. Notes of an interview, 28 Dec. 1900, with “B”, Mr Anthony Bowlby, surgeon to St Bartholomew's Hospital and also on active service in South Africa. He promised that he would see "C" and "D" (Drs Norman Moore and A. Willett) and advised Dowson to talk with "E" (Dr Frederick Andrewes). Moore was a prominent member of the RCP, and lecturer and assistant physician to St Bartholomew's; Willett was a Member of Council of the RCS from 1887-1903. Dowson's interview with Moore confirmed that any decision of the Laboratories Committee would have to be ratified by the Colleges' Councils before going to the HO: BW\&Co to Wellcome, 8 Feb. 1901, WF: Letter Books $c$. 1901, S/G/148/0, p. 86, memo. 291. See also note 172 below.

172 Op. cit., note 164 above. Notes of a "long interview", 3 Jan. 1901, with "E", i.e. Dr Frederick Andrewes, who immediately wrote an introduction for Dowson to Dr Sidney Martin: see note 166 above. Andrewes, later knighted, was a pathologist and bacteriologist, Kanthack's successor at St Bartholomew's: see note 67 above.

173 Op. cit., note 164 above. Note of an interview with "L", 22 Jan. 1901, probably Charles Stewart, FRS (1840-1907), Professor of Comparative Anatomy and Physiology at the RCS: J. Dobson, 'Conservators of the Hunterian Museum. V. Charles Stewart', Ann. Roy. Coll. Surg., 1962, 31: 46-51. Dowson requested an introduction to H. G. Howse, Surgeon to Guy's and a member of the Laboratories Committee, but Stewart was unable to oblige.

${ }^{174}$ Op. cit., note 164 above. Notes of an interview with “K”, Dr Frederick Gowland Hopkins, 18 Jan. 1901. Hopkins attributed the remark to "an eminent physiologist", possibly Sir Michael Foster.
} 
Wellcome therefore petitioned all the BMA's Council members, stressing the argument already used in connection with the WPRL, that the WRCL "as you probably know, are entirely separate and distinct from my business." 175

\section{THE HOME OFFICE DEBATES}

Wellcome's application, and the questions it promoted, led the Home Office to instigate enquiries along three lines: did the testing of diphtheria antitoxins cause pain in experimental animals? (it was universally acknowledged that other antitoxin testing was painful); could a central Testing Station be established and should it be under direct goverment control?; and was it desirable, and possible, to prosecute the WPRL or Dowson for infringement of the 1876 Act?

Thane investigated the first of these himself, visiting several laboratories to observe their experimental procedures. The majority, but not unanimous, view was that diptheria antitoxin testing did not cause pain. ${ }^{176}$

The second question was referred to both Royal Colleges, the Pharmaceutical Society, and the Jenner Institute. The problems of financing a central Testing Station seemed immense, as none of the bodies which supported such a venture was prepared to be responsible for its cost. The Government was unwilling to establish official laboratories itself, and Digby felt certain that if another body did not provide such facilities reasonably quickly, then the registration of the WPRL must be recommended. ${ }^{177}$

The third point was clearly related to the first question and to Dowson's position, as a licence-holder, under the law. This was the crux of the request for the legal opinion which the Home Secretary addressed to the Law Officers of the Crown. The first draft of this document stressed, somewhat inelegantly, that

the important question arises whether it is not doubtful whether such experiments are performed for "the purpose of advancing knowledge by new discoveries" as, if not, there appears to be no power to license them, and therefore, however useful, they

\footnotetext{
175 Wellcome to members of the BMA Council, 21 Nov. 1900, WF: Letter Books 1900-1901, S/G/148/1, pp. 468, 468a; Fawke to Jowett, 1 Nov. 1900, ibid., p. 469; Power to Fawke, 2 Nov. 1900, ibid., p. 470; Fawke to Power, 3 Nov. 1900, ibid., p. 471. In later years, similar "controversy with respect to the publication of papers" occurred with the Pharmaceutical Journal for similar reasons. Wellcome to Dowson, 31 Oct. 1904, WF:HSW Correspondence Personal 6 (1904-1905), p. 188; 11 May 1905, ibid., p. 448; British Pharmaceutical Conference, Minutes of Executive Committee, 1887-1911, 24 June 1904, pp. 268-9; 8 Aug. 1904 , p. $270 ; 8$ July 1907 , p. 318.

176 Thane observed inoculated guinea-pigs at the Conjoint Laboratories and the Jenner Institute, and questioned several bacteriologists about pain occurring during testing procedures. All notes and reports in PRO HO45/11092/B21744/27.

${ }^{177}$ Digby to Church, 12 May 1900, suggesting that if no other organization would undertake the responsibility, then the WPRL should be registered. PRO HO45/11092/B21744/15. A HO memorandum of 26 July 1900 acknowledges that whilst the Royal Colleges and the Pharmaceutical Society had stressed the desirability of independent laboratories, they had not offered to perform the task at their own expense, although "If a State Laboratory is not established, there would be no difficulty in finding Laboratories in London or elsewhere provided with the necessary appliances... Such laboratories might be used by authority of the Government for testing these remedies and for issuing certificates at such charges as would cover the expenses incurred". PRO HO45/11092/B21744/20.
} 
cannot be performed at all either with or without licence. If this were so, it is difficult to see how the important processes of standardising drugs and antitoxins can be carried on in any circumstances in which they would be calculated to give pain. ${ }^{178}$

The memorandum pointed out that, if the Law Officers decided that testing experiments were breaches of the Act, a difficult administrative situation would arise. Such work

will certainly be carried out by the Firm in France or Germany if not done here,- - they are no more painful than numbers that are now being done every day for the "advancement of knowledge" and other admittedly scientific purposes, and if they are rendered impossible an important and lucrative branch of trade will have been driven from our country, the results of which are most useful in saving life and alleviating suffering.

The Law Officers considered that testing procedures were to be regarded as experiments and that the Secretary of State could not make his annual renewal of Dowson's licence if he knew that the law was being broken, although Dowson should not be prosecuted for past misdemeanours. An internal memorandum maintained that the Secretary of State could not restrict experimentation at pleasure or out of sentiment but could only refuse if the objects of the research were considered to be useless and/or if unfit persons were proposed to perform them: "If this is so, it settles this case, when once we are satisfied of the nature of the arrangements made." The Royal College of Surgeons might perform such operations better, but they could hardly perform them more painlessly. If the Secretary of State was convinced that the experiments were useful and necessary and were to be performed by qualified persons, then he should register Wellcome's premises. Professor Thane remarked: "If the request were acceded to, the question of the illegality of the proceedings would fall through in this particular case. Therefore, I think Mr. Wellcome should be asked if he has any further statement to make." 179

\section{THE SECOND SUBMISSION: FEBRUARY TO SEPTEMBER 1901}

Wellcome had already started the preparation of a second submission to the Home Office in the light of the comments that Dowson received in the summer of 1900 . This new application, dated 25 February 1901 (a full year after the first) reveals several differences from the original. The first document's rather flamboyant but abstract phraseology was now replaced by precise responses to several questions. ${ }^{180}$

First, the independence of the WPRL from the business company was emphasized, as was the complementary role of the WRCL in the development of new drugs.

\footnotetext{
${ }^{178}$ Undated draft for the Law Officer's Opinion; Digby to Attorney General, 7 Jan. 1901, sought clarification of the Secretary of State's powers and responsibilities under the Act, and whether, if aware of some illegality, he was obliged to prosecute. PRO HO45/11092/B21744/28.

${ }^{179}$ Law Officer's Opinion, 14 Feb. 1901; HO Minute by Thane, 2 Mar. 1900; HO memo. 11 Mar. 1901. PRO HO45/1 1092/B21744/29. Thane advised that if a prosecution of Dowson failed, which he considered likely, then the 1876 Act would be discredited and "it would probably be necessary to have recourse to Parliament, with results that no-one can foresee". HO memo 12 June 1901: PRO HO45/11092/B21744/34.

${ }_{180}$ Draft of a petition from Wellcome to Thomson Ritchie, Secretary of State at the HO, 25 Feb. 1901, WF:WPRL Registration. Wellcome to HO, 25 Feb. 1901: PRO HO45/1 1092/B21744/30.
} 


\section{E. M. Tansey}

Detailed appendices listed several substances produced in the WCRL and awaiting physiological testing. Once more, however, the commercial argument was recognized:

at present Germany has the monopoly.... The petitioner, in his capacity as the principal of the firm of Burroughs Wellcome and $\mathrm{Co}$. is a purchaser of hundreds of thousands of pounds worth of chemicals which are not, but ought to be, made in this country.... It may be noted that the value of the British imports of chemicals and dyestuffs for the year ending 1899 was $£ 5,768,890 .{ }^{181}$

Additionally, Wellcome faced the criticisms raised in Dowson's interviews, declaring that the men he employed were all responsible scientific persons "guided by the same spirit and by the same aims as actuate all research workers". For a suitable physiologist he had "approached the highest authority in physiological science at one of our older Universities, ${ }^{182}$ and he maintained that it was particularly invidious to suggest that a well-trained man

would work in a proper spirit in his University laboratory and in an improper spirit in any other laboratory, his experiments being "humane" in the former case, and ipso facto losing this quality in the latter should it happen to be in any way connected with a commercial firm . . . the distinctions sometimes suggested between "experiments made for the purposes of trade" and "purely scientific experiments" are devoid of significance .... The experiments I desire to have conducted in my Physiological Laboratories would not be "for the purposes of trade." They would be made to enable the members of the medical profession to obtain in this country therapeutic substances with definitely ascertained properties and of known strength . . .. The spirit of research cannot be confined to institutions of learning. ${ }^{183}$

This argument was developed with regard to the contradictory criticisms presented earlier: if the WPRL was registered the Home Office would have to register inferior firms, but conversely, if no other companies were registered, then Wellcome might acquire a valuable monopoly. Wellcome countered

such distinction should depend on the fitness of the laboratories and of those who work in them ... that the possession of such a licence might be of value from a commercial point of view implies nothing more than that medical men would probably prefer to procure therapeutic substances from these firms who voluntarily accept the responsibility of standardising the strength of their products .... The initial outlay in the establishment of adequate provision for this kind of work, and the annual expense of its prosecution, are so great that, taken together with its inherent difficulties and

181 Ibid., Appendix A, pp. 8-11. Chemicals awaiting physiological testing included Jaborandi alkaloids, natural products such as Strophanus and willow bark, and synthetic compounds including new varieties of morphine and creosote.

182 Op. cit., note 180 above, p. 2. The "highest authority" was probably Sir Michael Foster, who had signed the first petition, and whom Dowson had approached in December 1900 on the matter. BW\&Co to Dowson, 5 Dec. 1900, WF:HSW Letter Books 1900-1901, S/G/148/1, p. 607. See also notes 98 , 117 and 190.

${ }^{183}$ Op. cit., note 180 above, pp. 3-4. A later comment by Lord Moulton (see note 58 above), that traditional attitudes in medical practice made the acceptance of new ideas particulary difficult, also emphasized that the concepts of "pure" and "applied" research were vague and artificial; in A. C. Seward (editor), Science and the nation, Cambridge University Press, 1917, pp. viii-xx. 


\section{The Wellcome Physiological Laboratories}

responsibilities, such applications are in my opinion likely to be rare. Should no other application be made, and the granting of such license be thought to practically confer a monopoly with respect to certain therapeutic substances, it appears sufficient to state that this result could follow only if other manufacturing chemists failed to incur the great expense necessary and to furnish adequate guarantees. ${ }^{184}$

These lengthy quotations indicate the force with which Wellcome now presented his request to the Home Office. Some of the assertions made in his first petition, especially on the basic need for laboratory testing, were included again in the new submission "I hold it to be wrong that a drug should receive an extensive trial lasting perhaps for years on the human subject without previous experiments on animals...the administration of all powerful or dangerous remedies should first have a sound basis in laboratory experiment."

In the middle of March there was an encouraging response from the Home Office in the form of a request for further details of experiments to be performed under licence and certificates, of who would be employed, and of the arrangements envisaged for planning and reporting experimental work. ${ }^{185}$ This was passed to Dowson, Smith, Chune Fletcher, and Fletcher Moulton, and "It was decided to immediately engage, if possible, another physiologist, upon the condition that the engagement should not be ratified unless we secured the license from the Home Office". This person was to provide the precise details required by the Home Office. Dowson was dispatched to interview Sir Michael Foster about a suitable candidate. ${ }^{186}$ The initial draft reply to the Home Office was more succinct than those previously submitted. It listed the nature and number of experiments desired during the first year (e.g. antitoxin work on typhoid, tetanus and snake-bite; standardization work on digitalis, ergot, and lobelia, and purely experimental work on supra-renal gland extracts) and described the staffing arrangements and organization of the different departments of the WPRL. ${ }^{187}$ Throughout are spaces "to be filled in by the new physiologist" and by the date of the next draft, 21 May, "the new physiologist" was named as John Mellanby of Emmanuel College, Cambridge, recommended to Wellcome by both J. N. Langley and F. G. Hopkins. ${ }^{188}$ This final version listed not only the number of experiments but also the

\footnotetext{
${ }^{184} \mathrm{Op}$. cit., note 180 above, pp. 2-3. D. H. Aldcroft argued that the coveted goal of the Victorian entrepreneur was to become one of the landed gentry, but Wellcome's aspirations were clearly different. 'The entrepreneur and the British economy 1870-1914', Econ. Hist. Rev., 1964, 17: 113-4.

${ }_{185}$ HO memo 11 Mar. 1901, PRO HO45/11092/B21744/29; HO to Wellcome, 21 Mar. 1901, PRO HO156/14 p. 545.

${ }^{186}$ BW\&Co to Wellcome, 4 Apr. 1901, WF:HSW Letter Books c. 1900, S/G/148/0, p. 550, memo. 456. Dowson consulted Brodie (see note 168 above), Starling, Sir John Burdon Sanderson and Schäfer (see note 117 above).

${ }^{187}$ Draft, Wellcome to HO, 2 Apr. 1901, WF:WPRL Registration. The letter cited in note 182 above emphasized the importance of reducing the number of experiments in the recognition that the most important goal was registration.

${ }^{88}$ BW\&Co to Wellcome, 3 May 1901, WF:HSW Letter Books c. 1900, S/G/148/0, p. 694. Mellanby, a "young man of great attainment and of a brilliant future", was employed because BW\&Co could not find the candidate they wanted. BW\&Co to Wellcome, 17 May 1901, ibid., p. 809, memo. 560. Mellanby's initial contract was conditional upon the registration of the WPRL: BW\&Co to Mellanby, 17 May 1901, ibid., p. 817 .
} 
certificates that would be required, as, for example, in the presentation of the proposed antitoxin work:-

(a) The injection of cultures of microbes into rodents, - chiefly guinea-pigs would be used-

about 50 experiments with typhoid cultures, certificate A about 50 experiments with tetanus cultures, certificate $\mathrm{A}$

about 50 experiments with snake venom cultures, certificate $A^{189}$

"It has undoubtedly the right swing about it now, which I feel we owe mainly to the kindness of Sir Michael Foster." 190 With this second submission was a formal application form to the Home Office, which Dowson had finally been advised to include. ${ }^{191}$

The file was once again passed to Professor Thane, who wrote a lengthy minute, weighing up the argumants for and against the registration of the WPRL. He made it clear that he considered it unreasonable to prevent a manufacturer from testing in guinea-pigs the serum he was allowed to raise in horses; and he emphasized the practical importance of such work, the eminent support that Wellcome had obtained, and the considerable development that was to be expected in such standardization work. These arguments were followed closely by Digby, who came "somewhat reluctantly to the conclusion that the application to register Messrs. Burroughs \& Wellcome's laboratories must be granted. I say 'reluctantly' because I think that besides the outcry which will no doubt be raised by the Anti-vivisectionists, the Home Office will be taking a new departure, which will lead to some difficulties, but which in my view is inevitable." 192 Thane was asked to visit the laboratories once more. Dowson was recalled from his annual holiday to Brockwell Hall and J. C. Smith visited the laboratories to ensure a special "clean-up", prior to the meeting. Thane saw nothing that required him to modify his previous inspection report and recommended registration. ${ }^{193}$

On 6 September 1901, a letter arrived at the Company Headquarters from the Home Office, announcing that the WPRL had been registered under the 1876 Act. Copies were immediately dispatched to Smith, Dowson, and Chune Fletcher, and to

\footnotetext{
${ }^{189}$ Wellcome to HO, 21 May 1901, ibid., pp. 834-6.

190 Telegram, Dowson to BW\&Co, 4 Apr. 1901; Dowson to BW\&Co, 21 May 1901, both in WF:WPRL Registration; BW\&Co to Moulton, 10 Apr. 1901, WF:HSW Letter Books $c$. 1901, S/G/148/0, p. 556. "The wording and arrangement of the list of proposed work for the first year was written out by Sir Michael himself": BW\&Co to Wellcome, 12 Apr. 1901, ibid., p. 565, memo. 462.

191 Dowson to BW\&Co, 21 May 1901, quoted in the letter cited in note 189 above; BW\&Co to Dowson, 22 May 1901, ibid., p. 839. The HO agreed that the proposals were "of [a] justifiable nature" and that after Thane had inspected the WPRL again, registration was likely. HO memo, 27 May 1901. PRO HO45/11092/B21744/32. 34.

192 HO Minute by Thane, 12 June 1901; note by Digby, 15 June 1901. Both in PRO HO45/1 1092/B21744/

193 Telegram, BW\&Co to Dowson, 14 Aug. 1901, WF:HSW Letter Books June to Nov. 1901, S/G/148/6, p. 281; BW\&Co to Dowson, 14 Aug. 1901, ibid., p. 282; BW\&Co to Thane, 15 Aug. 1901, ibid., p. 280. HO memo by Thane, 20 Aug. 1901, PRO HO45/11092/B21744/34. See also note 105 above. HO officials decided not to perform the "rather awkward task" of informing the Royal Colleges or the Pharmaceutical Society of their decision.
} 


\section{The Wellcome Physiological Laboratories}

Henry Wellcome in Switzerland, ${ }^{194}$ who was "gratified to learn that my physiological research laboratories have been registered as a place at which experiments on living animals may be performed." 195 In the same week a press report from the British Pharmaceutical Conference commented appreciatively on the standardization work undertaken by Parke Davis and Company in America. It concluded that although British firms were often reluctant to accept the financial responsibility of such work, the "Anti-Vivisection Act" also prohibited them from using such methods. ${ }^{196}$ The registration of the WPRL was about to change that situation.

\section{THE WPRL AFTER REGISTRATION 197}

Once registration was granted, the Company decided to extend their diagnostic services, and sought "a really able man". ${ }^{198}$ W. V. Shaw, a pathologist at St Mary's Hospital, London, was appointed at the beginning of January 1902, when John Mellanby, whose previous contract was subject to Home Office registration, was offered a permanent position. ${ }^{199}$ These contracts raised several problems because of their "commercial" character with regard to conditions of service, holiday allowances and, more importantly, restrictions upon publication.

It is understood that you are to treat as strictly confidential, and respect as my property, all my manufacturing processes, formulae, apparatus etc. and all improvements therein, and also any inventions or new discoveries which may be made by you or anyone else in my employment; on the understanding that I shall not extract from you with respect to any discovery a confidence which is contrary to the ethics of your profession.

It is also understood that before publishing any communications upon physiological matters or upon any work connected with the Laboratories you are first to submit same to and obtain the approval of the Director.

The two clauses just written refer to work done at any time either in or out of the Laboratories. ${ }^{200}$

The problem of offering such documents to scientific staff had been raised by Chune Fletcher, who complained that the wording was totally unsuitable. He maintained that the annual holiday allowance of three weeks was insufficient for a good professional

194 HO to Wellcome, 5 Sept. 1901; PRO HO156/14 p. 768, also advising that, as the Secretary of State believed antitoxin testing to come under the $1876 \mathrm{Act}$, licensees would require Certificates. Dowson to BW\&Co, 6 Sept. 1901; BW\&Co to Wellcome, 6 Sept. 1901. Both in WF:WPRL Registration. Antivivisectionists were informed of the registration; e.g. HO to International Anti-Vivisection Council, 26 Sept. 1901. PRO HO156/14 p. 784.

195 Wellcome to HO, 27 Sept. 1901, WF:HSW Letter Books June to Nov. 1901, S/G/148/6, p. 492.

196 Chem. \& Drug., 1901, 59: 412.

197 After registration, security at the WPRL was closely reviewed: BW\&Co to Wellcome, 19 Oct. 1901, WF:HSW Letter Books June to Nov. 1901, S/G/148/6, p. 672 memo. 817. Registration also brought the WPRL under the protection of the law, when, for example, stolen cats were mistakenly bought: see Chem. \& Drug., 1905, 66: 348, and several letters in WF: Letter Book HSW \& BW\&Co 1904-1906.

${ }_{198}$ BW\&Co to Plimmer, Burdon-Sanderson, and Ritchie, for references for Shaw, 20 Dec. 1901, WF:HSW Letter Books Nov. 1901-Feb. 1902, S/G/148/7, pp. 285-7.

${ }_{199} \mathrm{BW} \&$ Co to Shaw, 12 Dec. 1901, inviting him for an interview, ibid., p. 223. There is no indication that other candidates were considered, or had even applied. BW\&Co to Dowson, 20 Dec. 1901, ibid., p. 284; Wellcome to Shaw, 1 Jan. 1902, ibid., p. 440; Wellcome to Mellanby, 1 Jan. 1902, ibid., p. 441. See also note 188 above.

${ }^{200}$ E.g., Wellcome to Mellanby, ibid.; Mellanby to Wellcome, 15 Jan. 1902, WF:E2 DW, 'WPRL 1895-1922'. 


\section{E. M. Tansey}

man, and that this was exactly the kind of restriction that would prevent such a person joining, or remaining in, the laboratories. ${ }^{201}$ He became even blunter about the necessity of Company policy not upsetting work at the WPRL

so that they can make a thoroughly good start now that they are registered, every consistent concession should be made. The trouble and anxiety which we have had to secure men for these laboratories, has been exceedingly great, and one must not forget that the proportion of men sufficiently broad-minded to be associated with your laboratories is very small. With Dr. Dowson, Dr. Shaw and Mr. Mellanby we think there is a great opportunity for creditable work to be done at the laboratories, but they must have every encouragement and stimulant possible. ${ }^{202}$

In addition to serum production and diagnostic work, registration under the 1876 Act permitted Wellcome to employ physiologists and pharmacologists to prosecute "pure" research, and his most famous recruit was undoubtedly Henry Dale, ${ }^{203}$ who joined the WPRL in 1904. However, prejudices and misconceptions still prevailed and he was warned "I should be selling my scientific birthright . . . for a mess of commercial pottage", although "I never had serious or lasting reason to regret the change which I had made". ${ }^{204}$ Indeed, Wellcome's request to E. H. Starling for a reference for Dale again emphasized the laboratories' independence from the commercial organization, and that he was looking for

a man who is capable of broad and deep thinking, who has fertility of mind, originality and alertness, and patient persistence; a man who will concentrate his whole mind and energies on this work. I want the work in these laboratories to be done on the highest scientific lines and with such a thoroughness and precision that it will stand the test of time and the keenest criticism. ${ }^{205}$

Dale's arrival at the WPRL in 1904, and promotion to Director in 1906,206 deisinined very clearly the scientific direction of the research work undertaken there. Over 50 years later, he remarked upon "the absence, till then, of any real justification for the title 'Physiological Research Laboratories'. This was the name which had been given to them by Mr. Wellcome when he founded them ... and it was obviously represented his hopes and aspirations." ${ }^{207}$ A wide range of high-quality research work

${ }^{201}$ BW\&Co to Wellcome, 28 Dec. 1901, ibid., p. 329, memo. 1207.

202 BW\&Co to Wellcome, 31 Jan. 1902, WF:HSW Letter Books 1900-1901, S/G/148/6, p. 735, memo. 1461; 'Still growing', Chem. \& Drug., 1902, 61: 768.

${ }^{203}$ Dale worked at the WPRL until 1914, when he joined the new Medical Research Committee (now Council). Some of his work at the WPRL led to his receipt, jointly with Otto Loewi, of the 1936 Nobel Prize in Physiology or Medicine. W. S. Feldberg, 'Henry Hallett Dale, 1875-1968', Biog. Mems FRS Lond., 1970, 16: 77-174; see also H. H. Dale, Adventures in physiology, London, The Wellcome Trust, 1965.

${ }^{204}$ H. H. Dale, ‘Autobiographical sketch', Perspect. Biol. \& Med., 1958, 1: 125-37.

${ }^{205}$ Wellcome to Starling, 2 June 1904, WF:HSW Letter Book Personal 5, 1903-1904, S/G/148/6, p. 399.

${ }^{206}$ Dowson resigned when the U.S. Public Health Service refused to import BW\&Co's antitoxins because of contamination, albeit with a non-pathogenic organism. In a scenario reminiscent of Bokenham's story, Dowson rejected their findings. Wellcome referred to external experts and when they confirmed the contamination Dowson resigned, leaving Dale as the only person available to supervise serum production. Dale to Fowler, 20 June 1960; Fowler to Dale, 28 June 1960. Both letters RS: 93HD 65.5, Brockwell Hall, 1952-1967. See also Feldberg, op. cit., note 203 above, pp. 99-100.

${ }_{207}$ Address of Sir Henry Dale at the opening of new Wellcome laboratories, 1 May 1959, WF/95. They had not, of course, been known as the Physiological Laboratories from their foundation. 
was performed at the WPRL after the granting of Home Office Registration. ${ }^{208}$ One indication of the calibre of scientists recruited to the WPRL at Brockwell Hall is the number of them that were subsequently elected to Fellowship of the Royal Society. ${ }^{209}$

It is pertinent to consider two further questions: did the Home Office's registration of the WPRL open the flood-gates to numerous "commercial" applications? and did the registration of the WPRL itself greatly increase the total number of experiments performed under the 1876 Act?

\section{PHARMACEUTICAL COMPANIES AND HOME OFFICE REGISTRATION}

Difficulties with the Home Office were not entirely resolved with the granting of registration: in January 1902, Shaw applied for a licence and certificates to carry out cancer research. ${ }^{210}$ Not only was he identified in Home Office records as "a new Burroughs \& Wellcome man" but continuing doubts were expressed about the work of the WPRL: "This raises the question whether the Burroughs \& Wellcome Laboratories are to be used for general original research and diagnosis, or merely for the processes involving experiments under the Act, which are necessary for Messrs. B.\&W.'s business".211

Inevitably, Professor Thane was asked for his opinion, and he produced a five-page report on the practicability of limiting work at the WPRL. This emphasized the word "research" in the title of the laboratories and Wellcome's intention, implicit in his application, of prosecuting research not directly associated with serum production or drug standardization. Thane stressed his belief that an application merely for such procedures would have been refused, and maintained that

There is no doubt that Mr. W. desires to get research work done in, and scientific papers published from, his Physiological Research Laboratories, just as is the case with his Chemical Research Laboratories.

In the eyes of many persons it will be a merit that scientific work is done in the laboratory in addition to trade work.

\footnotetext{
208 After registration until the WPRL moved in 1922, over 125 papers were published on physiological, pharmacological and bacteriological topics. A brief review may be found in J. Vane, 'The research heritage of Henry Wellcome', Pharmaceut. Hist. 1980, 10: 2-8. See also Kellaway, op. cit., note 19 above; and MacDonald, op. cit., note 5 above, pp. 71-89.

${ }^{209}$ Details taken from Staff Record Book 1879-1902, WF:P2 and the typescript 'History of the Firm file', op. cit., note 19 above. Dale (op. cit., note 203 above), Glenny (op. cit., note 92 above) and J. W. Trevan (1887-1956) were all honoured whilst employed by Wellcome, although Dale's election coincided with his resignation. Dale to Wellcome, 1 May 1914, RS 93HD 64.2, Personal File Correspondence 1904-1948. Later Fellows who were early WPRL employees include John Mellanby (1878-1939); A. J. Ewins (op. cit., note 94 above); G. Barger (1878-1939); Edward Mellanby (1884-1955); P. P. Laidlaw (1881-1940); H. King (1887-1956); J. H. Burn (1892-1981); and Percival Hartley (1881-1957). Details of their careers, including time at the WPRL, may be found in the Obituary Notices or Biographical Memoirs series of the Royal Society. Dale was later involved in Wellcome himself being created FRS: Elliott to Dale, 25 Nov. 1931, RS 93HD T. R. Elliott 36.4.4.; Dale to Elliott, 26 Nov. 1931, ibid., 36.4.5.

210 Dowson believed that work on cancer would bring credit to the WPRL: BW\&Co to Wellcome, 28 Dec. 1901, WF:HSW Letter Books Nov. 1901 to Feb. 1902, S/G/148/7, p. 327, memo. 1203. Applications by W. V. Shaw, for licence and certificates A and B. 31 Jan. 1902, PRO HO144/640/B37553.

211 Memo, 25 Feb. 1902, PRO HO144/640/B37553.
} 


\section{E. M. Tansey}

He concluded that work by a licence holder on registered premises could only be limited by refusing applications for additional certificates, and that the proposed work was perfectly proper.

I looked upon it as certain, when registration was granted, that the thing would develop, but one could not see exactly on what lines. I consider the certificates submitted by Mr. W. Vernon Shaw to be quite consistent with the objects set forth by Mr. Wellcome in his application for registration. ${ }^{212}$

Home Office files contain additional correspondence about Shaw's certificates, his subsequent work and the resultant publication, but after Thane's memorandum there appears to have been no further question about the research role of the WPRL.

A fear which had been consistently expressed during the period of Wellcome's application was, that if it were successful, it would create a dangerous precedent for the registration of other commercial premises. However it was over four years before the Home Office next received an application from a pharmaceutical company. In November 1905, Brady \& Martin, from Newcastle-upon-Tyne, applied not only for registration but also for a licence for Dr William Martin. Their submission has a familiar ring: "The grounds upon on which the application is made are that during late years there has been an ever increasing demand for medicines which have been certified to come up to a required standard". After listing the work in this direction of Parke Davis and Company, Mulford, and Sharpe and Dohme in America, it concludes "Finally, Messrs Burroughs, Wellcome and Co. have had a license [sic] granted to them for making experiments on animals in this country."213

Although Brady \& Martin's staff did not even include an Home Office licensee, ${ }^{214}$ unlike Wellcome's when he applied, the Home Office did accept the precedent of the WPRL registration. A note in their files by Sir James Russell, the Inspector for the North of England and Scotland, contains some intriguing remarks in the light of the problems that had faced Henry Wellcome, "Brady \& Martin Limited is a purely English company of the highest standing. The Directors are scientific men who are much respected and who do not put mere money considerations in the first place in the conduct of their business". After commenting that one of the principals, N. H. Martin, was a local magistrate and known to him personally, Russell continued: "The principle of registration has been settled already by the grant of registration to Burroughs \& Welcome [sic], a firm of American origin." Russell's recommendation was annotated by the Chief Inspector, Thane, "Wellcome's laboratories having been registered it is not possible to refuse the demand of another manufacturing chemist who makes satisfactory arrangements as to place $\&$ person." 215 A further memorandum reiterates

212 Thane memo, 8 March 1902, PRO HO144/644/B37553/1.

213 Martin to HO, 8 Nov. 1905, PRO HO144/738/114089/2.

214 Several incomplete applications had been submitted during the time of Wellcome's own petition, e.g. registration was requested for the Physiological Laboratory, University College, Bristol. Thane admitted "There is no special animal house at present", but recommended registration, 17 Oct. 1900, PRO HO144/970/B32790/1.

215 HO Minute by Sir James Russell, 15 Nov. 1905; HO Minute by Thane, 17 Nov. 1905, quoting Russell's letter, PRO HO144/738/114089/2. 


\section{The Wellcome Physiological Laboratories}

the importance of precedent, ${ }^{216}$ the very argument that caused so much concern at the time of Wellcome's original petition: "The principle having once been established in that case [i.e., that of the WPRL] it would be difficult to refuse a similar privilege to a purely English firm like Messrs Brady \& Martin who seem to be of the highest standing". 217 The final entry in the Home Office file reads "There seems no doubt that if one place is licensed, another ought to be if sufficiently equipped to do the work satisfactorily ... If the toxin is not made in England, the manufacturers will only have to go to Germany. The demand exists and must be satisfied somehow."218 Within three weeks of submitting their request, the premises of Brady \& Martin were registered under the 1876 Act, and Dr William Martin was granted a personal licence. There is no evidence that the Home Office consulted other bodies about the application, or that there was any serious debate over the granting of the request. ${ }^{219}$

Over ten years later, in 1916, the laboratories of the next pharmaceutical company, May \& Baker, in Wandsworth, South London, were registered. ${ }^{220}$ By this time there had been a marked increase in the number of registered places, mainly due to wartime contingencies. (In 1916, 22 new places were added to the Home Office Register, bringing the total to over 160, compared with 96 in 1913). 1919 saw the registration of premises belonging to Nathan and Company in London, and Lever Brothers in Port Sunlight; and the following year five more commercial premises achieved registration as well as two more Wellcome premises: the Wellcome Bureau of Scientific Research at Endsleigh Gardens, London and their subsidiary Field Laboratories at Ripley, the site of the Wellcome Entomological Laboratories. ${ }^{221}$ By this time there seems to have been no debate at all about the suitability of "commercial" companies for the privilege of registration, and such applications were routinely considered along with those from hospitals and university departments.

An important complementary issue is the impact that the registration of the WPRL had on the Annual Returns of Experiments. There had been a steady increase in the numbers of licensees, registered places and experiments performed from 1893 until 1901, and this trend continued from 1902 onwards. ${ }^{222}$ A summary of the relevant figures is shown in table 2.

There was an increase in all categories between 1901 and 1902, partly due to the "accounting" procedures adopted by the Home Office, as licensees submitted their

\footnotetext{
216 Precedence frequently determined policy. When the first Municipal Laboratory was registered in 1899 for example, it had "raised a general question", and was subsequently used to justify similar applications, HO Report by Russell, 5 Mar. 1900, PRO HO144/451/B.30824A/1.

${ }^{217}$ HO memo, Nov. 1905, PRO HO144/738/114089/2. No hint of this chauvinist attitude emerged during Wellcome's application.

218 HO memo, 21 Nov. 1905, PRO HO144/738/114089/2.

${ }^{219}$ For this three-week period, no evidence of relevant correspondence in HO records, Council Minutes of the RCS or comment in the Press has been located, in striking contrast to the discussions that accompanied Wellcome's application.

${ }^{220}$ HO Returns, 1916. The Runcorn Research Laboratories, started by C. S. Sherrington and Liverpool colleagues, provided facilities for the study of comparative pathology and for the raising of antitoxins and vaccines, and were associated with the Evans Medical Company. They were registered with the Home Office in 1910, but their role within the company has not been ascertained. The story of Evans Medical 1809-1959, Evans Medical Supplies Limited, Liverpool, n.d.; Nature, 1937, 140: 676.

${ }^{221}$ HO Returns, 1917.
} 


\section{E. M. Tansey}

Table 2: Summary of the Returns of Experiments, 1900-1903

\begin{tabular}{ccccccc} 
& \multicolumn{2}{c}{ Licensees } & \multicolumn{3}{c}{ Experiments } & Certificate \\
& Total & Active & places & \multicolumn{2}{c}{ under } & and \\
& 247 & 184 & 47 & 1885 & 8954 & 'A' \\
1900 & 257 & 201 & 52 & 2049 & 9596 & 8825 \\
1901 & 319 & 207 & 59 & 2130 & 12,776 & 12,630 \\
1902 & 347 & 250 & 72 & 2171 & 16,913 & 16,712 \\
1903 & & & & &
\end{tabular}

Annual Returns at the end of February 1903 instead of December 1902, to coincide with the licence renewal date. Thus for the 1902 returns, the figures refer to a period of 14 months (January 1902 to February 1903) compared with the figures for the previous 12-month period (January to December 1901). Even so, a crude analysis of "experiments per month"- 792 in 1901,902 in 1902-indicates a very real increase in the number of experiments. The increase in the number of licensees, 62 during this year, was specifically referred to in the Chief Inspector's report to the Secretary of State, where it was explained by the extended time period of analysis. Although this may be true, it does not account for the increase in the number of experiments performed. The Home Office was concerned to justify the increase in animal usage, particularly the large number of experiments performed without anaesthetic, and to relate these to public utility. The Inspector emphasized that, of the 12,776 such experiments in 1902, over half were undertaken by just 23 licensees testing antitoxins or performing inoculation experiments on behalf of such official bodies as the Local Government Board, the House of Commons Ventilation Committee, the Royal Commission on Tuberculosis, the Board of Agriculture, and several County Councils and Municipal Corporations. Much of the work involved testing milk, the examination of hair for contamination with anthrax, or the testing of sewage effluent.

Was the registration of the WPRL a significant factor in this increase?223 When the WPRL was registered, Dowson was the only licensee there, and his licence was also available at the New Museums site in Cambridge. In December 1901, John Mellanby's licence became available for the WPRL, in addition to the Cambridge site. Their returns for 1901 were both modest: Mellanby performed 17 licence-only experiments (out of the total of 1,176 such experiments) and Dowson made 127 experiments under Certificate A (out of 9,504 ' $A$ ' returns). It is not possible to ascertain where the work was done, although most of it was undoubtedly done for the WPRL. In 1902 there were three licensees at the WPRL, Dowson and Mellanby with their dual availability, and W. V. Shaw with availability only at the WPRL. Again, it is not possible to tell precisely where the work was performed, but it is unlikely that once the WPRL were registered it was either necessary or desirable for employees to work elsewhere. These three men performed 2,366 experiments, out of the annual

\footnotetext{
222 See also French, op. cit., note 3 above, pp. 392-405.

${ }^{223}$ Details of experiments performed by licensees at the WPRL are taken from HO Returns for the relevant years.
} 
total of 14,906, and thus contributed substantially to the increased returns for 1902 . When the returns under A certificates are analysed separately, it can be seen from table 2 that the increase in such returns between 1901 and 1902 is 3,216, and of these 2,261 were experiments reported from the WPRL. In 1908, eleven licences were available at the WPRL, and they performed at least 5,266 experiments out of a total of $88,634 .^{224}$ Thus in those six years the Wellcome returns had doubled, although the total returns had increased by almost a factor of six. The registration of the WPRL and similar "commercial" laboratories did not, therefore, increase the animal experimentation figures as significantly as had been feared during Wellcome's application for registration.

\section{CONCLUSION}

In 1921 Burroughs Wellcome and Co.'s lease on Brockwell Park was running out, with no possibility of renewal. ${ }^{225}$ Eventually, new property was acquired in Beckenham, at Langley Court. Although there was some local opposition to the enterprise, strong offical support for the laboratories and their work was forthcoming. ${ }^{226}$ Henry Wellcome's sustained but ultimately successful application had convinced the Home Office and much of the medical profession that research on "commercial" premises was not necessarily tainted or substandard. The new premises were registered by the Home Office without demur, ${ }^{227}$ and Wellcome's Physiological Research Laboratories subsequently provided facilities and opportunities that completely justified the optimism expressed by Henry Dale in a letter to Henry Wellcome in 1906, “. . . I hope some day to see the aid of commerce by physiology recognised as an important $\&$ desirable brand of medical science in England, \& to see your laboratories recognised as the pioneer institution.",228

\section{ACKNOWLEDGEMENTS}

I am particularly grateful to Dr W. F. Bynum for his many helpful comments and criticisms of drafts of this paper. For sharing their knowledge of Wellcome history, and for reading an earlier version of the manuscript, I thank Mrs R. C. E. Milligan and Mr H. J. M. Symons; and I am indebted to Col. R. S. Vine for his authoratitive assistance with Home Office documents and also for reading a draft of this paper. I am obliged to Dr D. Gordon, Professor Sir William Paton FRS, and Professor M. Weatherall for their useful comments on the manuscript. The secretarial assistance of Mrs H. M. Tansey and Miss S. M. Bragg is much appreciated; and I am most grateful to The Wellcome Trust for their financial support of this research.

\footnotetext{
${ }^{224}$ Of the eleven people with licence availability at the WPRL, only the returns of the six WPRL employees have been considered

${ }^{225}$ The WPRL buildings were demolished shortly after 1922. WF/134 Recent Acquisitions: typescript history of Brockwell Park.

${ }^{226}$ HO Returns 1921 and 1922, when there were at least 25 licences available at the WPRL, 10 of them belonging to women.

227 There was some hostility at Beckenham to the relocation of the WPRL, WF:DW WPRL Beckenham 1922 onwards. An article headed 'Opposition to proposed laboratory' reports, "Sir Albion Richardson, for Mr. Wellcome, said that a laboratory instituted by him at Brockwell Park had been of the highest national utility, and during the war the Army was mainly dependent upon it for its supplies of serum", Chem. \& Drug., 1921, 94: 639.
}

${ }_{228}$ Dale to Wellcome, 14 Mar. 1906, WF:E2 DW, 'WPRL 1895-1922'. 